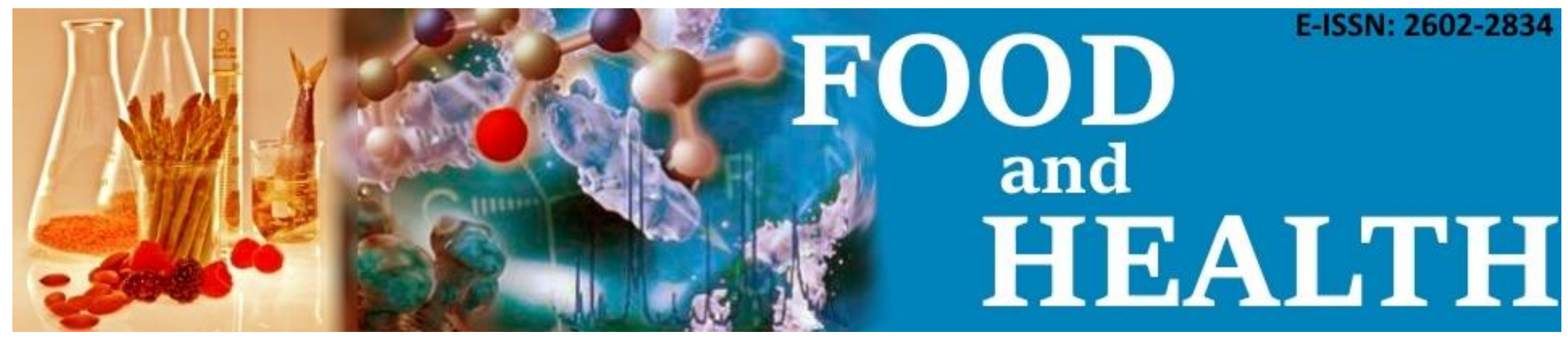

\title{
THE EFFECT OF USING FROZEN RAW MATERIAL AND DIFFERENT SALT RATIOS ON THE QUALITY CHANGES OF DRY SALTED ATLANTIC BONITO (LAKERDA) AT TWO STORAGE CONDITIONS
}

\author{
Serkan Koral $^{\text {idD }}$, Sevim Köse ${ }^{2}$ iD
}

Cite this article as:

Koral, S., Köse, S. (2018). The Effect of Using Frozen Raw Material and Different Salt Ratios on the Quality Changes of Dry Salted Atlantic Bonito (Lakerda) at Two Storage Conditions. Food and Health, 4(4), 213-230. DOI: 10.3153/FH18022

1 İzmir Katip Celebi University, Faculty of Fisheries, 35620 Çiğli, İzmir, Turkey

${ }^{2}$ Karadeniz Technical University, Sürmene Faculty of Marine Sciences, Department of Fisheries Technology Engineering, 61530, Çamburnu, Trabzon, Turkey

Submitted: 08.09.2017

Accepted: 13.02.2018

Published online: 01.04.2018

Correspondence:

Serkan KORAL

E-mail: serkan.koral@ikc.edu.tr

๑Copyright 2018 by ScientificWebJournals

Available online at

www.scientificwebjournals.com

\begin{abstract}
This study identifies the effect of freezing raw material on the storage quality of salted Atlantic bonito (Lakerda) at refrigerated $\left(4 \pm 1^{\circ} \mathrm{C}\right)$ and ambient $\left(17 \pm 3^{\circ} \mathrm{C}\right)$ conditions. It also shows the effect of different salt:fish ratios on the shelf-life and biogenic amine development during storage. The products with the lowest salt content corresponded to the lowest sensory acceptance. Previously frozen raw material (FRM) had higher salt uptake compared to freshly salted fish (FSF). Water phase salt (WPS \%) level usually reached to suggested seafood safety levels (20\%) within the $1^{\text {st }}$ week. There were significant differences $(\mathrm{p}<0.05)$ amongst the samples treated with different salt ratios and stored at different temperatures. Higher salt content caused higher thiobarbituric acid value indicating acceleration of lipid oxidation. Lower biogenic amine values were observed with products produced from FRM. Overall results demonstrated the advantage of using FRM for dry salting of Atlantic bonito in terms of food quality.
\end{abstract}

Keywords: Atlantic bonito, Frozen fish, Dry salting, Lakerda, Quality changes, Salt concentration 


\section{Introduction}

Atlantic bonito (Sarda sarda, Bloch 1793) is known as a commercially important fish species in the world (Turan et al., 2006). It is an epipelagic and highly migratory fatty fish which belongs to Scombridae family. This species has a wide geographical distribution and occurs throughout Atlantic Ocean, the Mediterranean and its adjoining seas (Zaboukas et al., 2006; Ateş et al., 2008). The world production of this species was 33651 tons in 2014, and Turkish production was 19031 tons in the same year (FAO, 2016a; TUIK, 2016). The catch in Turkey occurs primarily in the Black Sea and Marmara Sea (Ateşet al., 2008).

Atlantic bonito contains high amount of fat and therefore, it is more prone to oxidation and spoilage compared with less fatty fish (Zaboukas et al., 2006). Since it belongs to scombroid fishes, which are typically implicated in histamine seafood poisoning, it carries high histamine health risk if improperly handled (Lehane and Olley, 2000). The high level of free histidine in dark muscle, is susceptible to bacterial decomposition and thus to an accumulation of histamine (FDA, 2011; FAO-WHO, 2013). The past research demonstrated the presence of biogenic amines, particularly unsafe histamine levels in various commercially produced salted Atlantic bonito products (Köse et al., 2012; Koral et al., 2013). Koral and Köse (2012) reported limited shelf-life for fresh Atlantic bonito stored at refrigerated temperatures without ice as 4 days. Using ice only extended shelf-life for 3 more days. Due to short storage life of fresh Atlantic bonito at chilled storage, it is often marketed either as frozen or as salted and smoked products. Lakerda (a traditional salted fish product of Turkey and Greece) is originated from large Atlantic bonito with the sizes of $50-60 \mathrm{~cm}$, later smaller sizes of bonito $30-40 \mathrm{~cm}$ are used due to reduction in its large size population (Kahraman et al. 2014). It is marketed either at refrigerated storage or at room temperature if processed and sold by retail processors (Koral et al., 2013).

Atlantic bonito is caught seasonally and therefore, is usually frozen or salted during high fishing season due to its limited shelf-life and high histamine health risk. On the other hand, this species has a better market value and consumer acceptance when marketed either as smoked or salted in comparison to frozen unprocessed products. Therefore, further processing of frozen Atlantic bonito into salted or smoked products is of interest to seafood industry. Previous studies on salted Atlantic bonito was usually carried out on lakerda which is mainly processed from this species (Köse et al., 2012). Recently, lakerda production was also applied to different fish species such as mackerel and salmon (Köse et al., 2012). It is consumed without further heating and belong to group of the ready-to-eat products (Erkan et al., 2009).
There are at least 5 different lakerda production methods observed by our research team. The main processing line involves dry salting of the raw material for 1-5 days, then the processors either continue with dry salting by replacing the brine or carry on with brining. The products are matured within a month and then the products are stored in oil, brine or other seasoned solutions in plastic packs, glass jars or as vacuum packed.

Different factors can affect the quality and safety of lakerda. Past research on dry salted Atlantic bonito was usually concentrated on estimating the shelf life of lakerda. Its shell-life is usually around 3 months in cold storage although varying shelf lives were reported by different studies depending on the storage temperature, and processing and/or packaging methods (Köse et al. 2012). Lüleci (1991) obtained 60 days of shelf-life for this product stored in brine at $4{ }^{\circ} \mathrm{C}$. Erkan et al.(2009) investigated the effect of vacuum packing on the shelf-life of lakerda from previously frozen Atlantic bonito. They stored the products in different packing methods such as in glass jar containing oil, in glass jar with brine and vacuum pack in brine. Sensory results of their research showed that all the products spoilt after $14^{\text {th }}$ week at cold storage. Therefore, they demonstrated that packaging methods used did not make significant differences in sensory values. Turan et al. (2006) and recently, Kocatepe et al. (2014) also investigated the shelf-life of dry salted Atlantic bonito (lakerda) at refrigerated storage. However, both studies did not determined the sensory values, and the shelf stability of the products was judged using chemical and microbiological quality parameters. Therefore, their results cannot be evaluated into storage life without sensory values.

Studies on the effect of using different salt:fish ratios on the quality and safety of dry salted Atlantic bonito during storage are scarce. Since bonito is usually frozen immediately after catch prior to further processing during high fishing season, it is important to know the effect of freezing raw material on the quality of lakerda. Moreover, previous investigations showed that processing and marketing lakerda at room temperature are commonly applied by the retail processors while refrigerated storage is more common at factory scale producers (Koral et al., 2013). Therefore, it is also important to identify the effect of storage temperatures in terms of food safety and quality of lakerda. No study exists either on the effect of freezing raw material or storage temperature on the quality and safety of lakerda made from Atlantic bonito.

The aim of this study was to identify the effect of freezing of raw material on the storage quality of lakerda produced from Atlantic bonito at refrigerated $\left(4 \pm 1^{\circ} \mathrm{C}\right)$ and ambient 
$\left(17 \pm 3^{\circ} \mathrm{C}\right)$ conditions. Moreover, we also aimed to determine the effect of different salt:fish ratios during salting on the shelf-life and biogenic amine development during storage.

\section{Materials and Methods}

\section{Sampling plan and sample preparations}

Atlantic bonito was obtained from Trabzon (Turkey) whole market and transported to the laboratory in cold chain within $1 \mathrm{~h}$. The mean size of fish used was $39.95 \pm 1.63 \mathrm{~cm}$, the average weight was $672.00 \pm 85.24 \mathrm{~g}$. After heading and gutting, the fish were washed three times with chilled water in ice and kept in chilled water in $1 \mathrm{~h}$, and washed again. The raw material was firstly divided into two batches. The

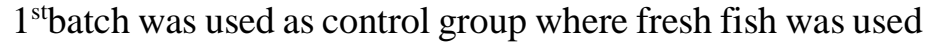
for salting. The $2^{\text {nd }}$ batch was frozen at $-40^{\circ} \mathrm{C}$, then stored at $-20^{\circ} \mathrm{C}$ for a month. Then, the fish was defrosted in a cold store room $\left(4 \pm 1^{\circ} \mathrm{C}\right)$ for 16 hours before processing (Figure 1). Each batch was subdivided into 3 groups before dry salting employing three different salt:fish ratios as 1:3, 1:4, 1:6 $(\mathrm{kg}: \mathrm{kg})$. The fish were cut into pieces as $4-5 \mathrm{~cm}$ in width before placing into glass jars, with alternating layers of salt and fish. After salting, each group was split into two subgroups, -one was stored at ambient $\left(17 \pm 3^{\circ} \mathrm{C}\right)$ temperature and the other was kept at cold storage at $4 \pm 1^{\circ} \mathrm{C}$ for 3 months (Table 1). Chemical, physical and sensory analyses were carried out to determine changes in quality and the level of biogenic amine changes.

\section{Chemicals and Reagents}

Salt (Rock salt; Billur Tuz, İzmir, Turkey) was obtained from a supermarket.All chemicals and solvents used were analytical and chromatographic grade, respectively. They are purchased from Sigma-Aldrich and Merck.

\section{Chemical Analysis}

Moisture content was determined by oven drying of $5 \mathrm{~g}$ fish muscle at $105^{\circ} \mathrm{C}$ until a constant weight was obtained (AOAC 1995, Method 985.14). Results were expressed as $\mathrm{g}$ water/100g muscle. Dry matter value was calculated from the results of moisture contents. Mohr method was used to determine salt content $(\mathrm{NaCl})$ in fish muscle as described in Rohani et al. (2010). Water Phase Salt (WPS) was calculated from the amount of salt in the product relative to the product moisture and salt content, using the following equation (Losikoff, 2008);

WPS $\%=[$ salt $\% /($ salt $\%+$ moisture $\%)] \times 100$
The method of Lücke and Geidel (1935) was used to determine total volatile base-nitrogen (TVB-N) content as described by Goulas and Kontominas (2005). TBA values, expressed in $\mathrm{mg}$ malonaldehyde (MDA/kg), were estimated by using the method of Tarladgis et al. (1960) described by Smith et al. (1992). The method of Boland and Paige (1971) was used for trimethylamine (TMA) analysis. Biogenic amines were analysed using high performance liquid chromatography (HPLC) method according to Köse et al. (2011) as modified from Eerola et al. (1993). HPLC equipment was Shimadzu Prominence LC-20 AT series (Japan) HPLC with autosampler (SIL20AC, Shimadzu, Japan), Diode Array Detector (SPD-M20A, Shimadzu, Japan) and Intertsil column (GL Sciences, ODS-3, $5 \mu \mathrm{m}, 4.6 \times 250 \mathrm{~mm}$ ). This method is an originated from EU suggested methods (EC Directive 2005a). Triplicated sampling was carried out and measured separately per group at each sampling point.

\section{Sensory Analysis}

Sensory analyses were performed by using modified method derived from the methods of Amerina et al. (1965), Karaçam et al. (2002) and Archer (2010). Salted fish samples were assessed on the basis of appearance, odour and texture characteristics. Eight trained panellists judged the overall acceptability of the samples using ten point descriptive scale. According to the scale, sensory evaluation of samples is as 10-9: excellent, 8-7: good, 6-5: medium, 4: the 'limit point' for acceptable/unacceptable and $<4$ : unacceptable.

\section{Other Measurements}

Water activity $\left(\mathrm{a}_{\mathrm{w}}\right)$ was measured using an AQUALAB TE3 model water activity meter according to principals described in Minegishi et al. (1995). The $\mathrm{pH}$ measurements were taken with a digital $\mathrm{pH}$ meter (Jenco 6230N, CA, USA) by placing the electrode into the samples where $5 \mathrm{~g}$ of fish flesh had been homogenized with $10 \mathrm{~mL}$ of distilled water. Readings were carried out for both $\mathrm{a}_{\mathrm{w}}$ and $\mathrm{pH}$ in triplicate.

\section{Statistical Analysis}

The data obtained were analysed by analysis of variance (one way ANOVA) and when significant differences were found, comparisons among means were carried out by using a Tukey and Mann Whitney U test (data not provided in the normality of assumptions) under the program called JMP 5.0.1 (SAS Institute. Inc. USA) and SPSS (SPSS Inc., Chicago, IL) (SokalandRohlf, 1987).A significance level of 95\% ( $\mathrm{p}<0.05)$ was used throughout analysis. 


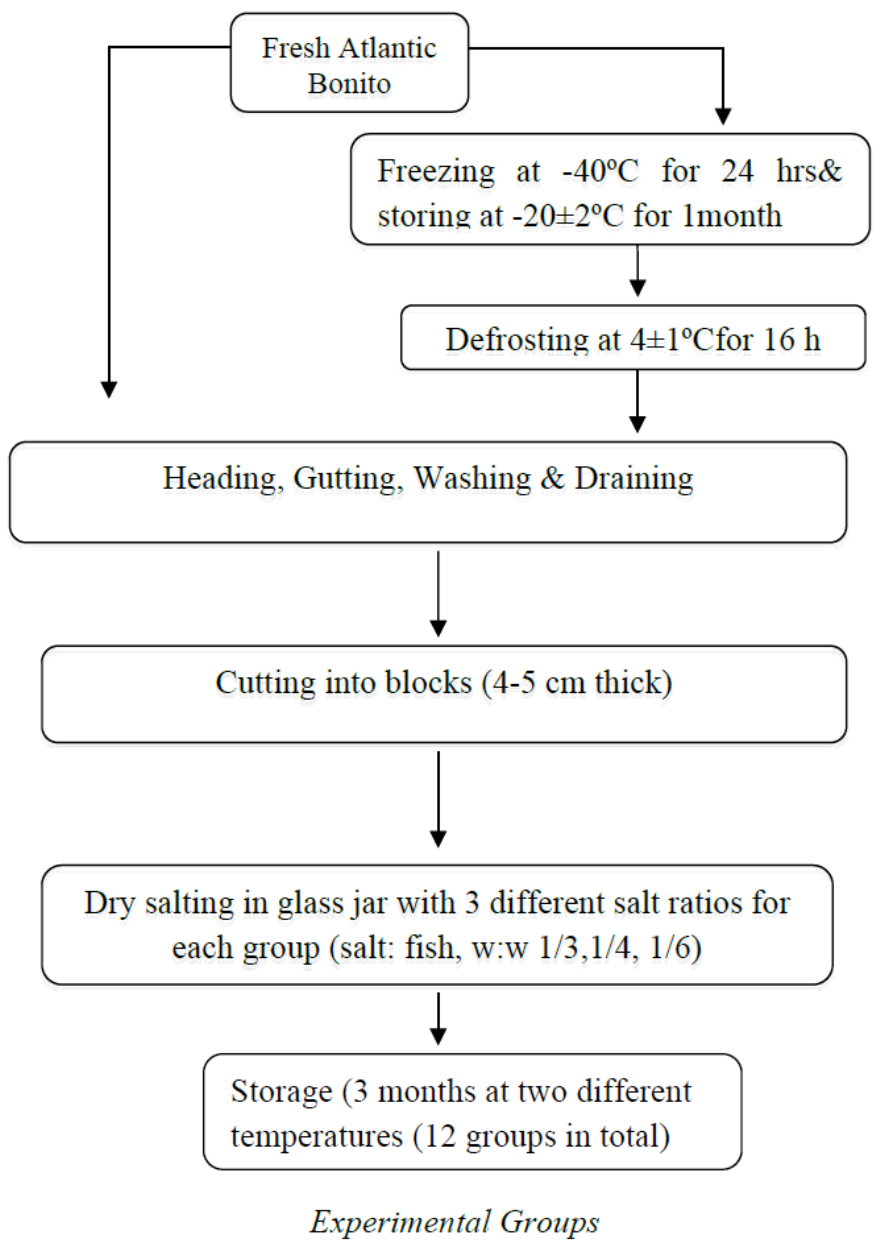

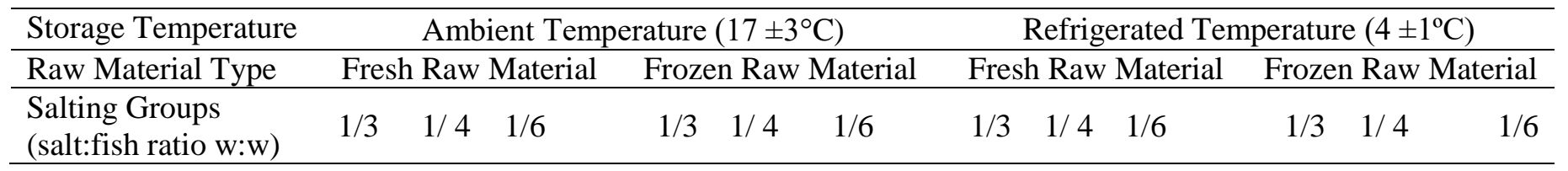

Figure 1. Processing outline and experimental groups

\section{Results and Discussion}

Tables 1-3 show the changes in the contents of $\mathrm{pH}, \mathrm{a}_{\mathrm{w}}$, dry matter, salt and WPS \% of lakerda samples originated from fresh and previously frozen raw material during storage at two different temperatures.

The percentages of dry matter in the fish flesh increased significantly $(\mathrm{p}<0.05)$ in all groups during the $1^{\text {st }}$ week from $36.86 \%$ up to $53.14 \%$ and from $37.12 \%$ up to $54.87 \%$ for fresh and frozen raw material groups, respectively depending on the ratio of salt:fish used (Table 1).The rise in the values continued significantly $(\mathrm{p}<0.05)$ for some salt:fish ratio groups during the $2^{\text {nd }}$ week. The highest dry matter value was found with the highest salt concentration due to higher diffusion rate of salt and water in and out of fish flesh, respectively. Moreover, dry matter values were usually higher for the products produced from frozen raw material in comparison with fresh raw material with significant variations within some salt:fish ratio groups $(\mathrm{p}<0.05)$.

The percentages of salt and WPS contents showed a similar trend as dry matter contents of lakerda (Table 2). As expected, the highest salt content was obtained in products salted with the highest salt concentration.The values in- 
creased significantly $(\mathrm{p}<0.05)$ during storage with some exceptions. Significant variations were also observed amongst all groups $(\mathrm{p}<0.05)$ indicating the significant effect of the storage temperature and the ratios of salt:fish used on the salt uptake. Apart from its preserving effect on spoilage, salting is also used to prevent seafood health hazards by both its direct effect on pathogenic microorganisms and decreasing the water activity of the food to limit microbial growth or toxin formation (Köse, 2010). Erkan et al.(2009) reported that lakerda is characterized by a salt content of $15 \%$. Our results showed that the suggested salt content was reached for the samples treated with the ration of $1 / 3$ (salt:fish) at the first week of storage at both temperatures in a range of 16.1$17.3 \%$ with the exception of the products prepared from frozen fish kept at refrigerated temperature that reached a salt level as $15.5 \%$ on the $8^{\text {th }}$ week. The results also indicated that such amount of salt can be obtained with a ration of $1 / 4$ salt:fish if fresh raw material used and product stored at ambient temperature. The lowest salt uptake was obtained for products prepared from frozen raw material and kept at refrigerated temperature.

Water phase salt is known as the amount of salt in the product relative to the product moisture content (Losikoff, 2008). Above 15-20\% WPS in the products is usually necessary to prevent seafood health hazard (Köse, 2010). Although salt content retards bacterial spoilage, halotolerant and halophilic histamine forming bacteria have been reported to grow well in $12 \% \mathrm{NaCl}$ broth (Lakshmanan et al. 2002). Among these halotolerant bacteria, Staphylococcus sp., Vibrio sp. and Pseudomonas sp. have been identified as the major halotolerant histamine forming bacteria (Lakshmanan $e t$ al., 2002; Hernández-Herrero et al., 1999). FDA (2011) reported Staphylococcus aureus as the highest salt tolerant bacteria which can grow at WPS as high as $20 \%$ although toxin formation is prevented above 10\%. WPS level of freshly salted Atlantic bonito reached to safety levels within $1^{\text {st }}$ week after salting for salt:fish ratios of $1 / 3$ and $1 / 4$, at both temperatures. However, WPS level reached to $20 \%$ for the salt:fish ratio $1 / 6$ on the $4^{\text {th }}$ week at ambient temperatures and after two months at refrigerated temperatures $\left(4 \pm 1^{\circ} \mathrm{C}\right)$. Similar trend was found for lakerda processed from previously frozen raw material. Koral et al. (2013) reported halophilic bacteria counts were usually within acceptable levels for commercial lakerda products sold at refrigerated temperatures, while the high values were found for the products obtained from retail processors kept at ambient temperatures.
In comparison to the present study, Ormanc1 and Colakoglu (2017) obtained higher salt levels and WPS\% in their lakerda samples matured at different temperatures $(4,15$ and $20^{\circ} \mathrm{C}$ ) with the highest value corresponding to $15^{\circ} \mathrm{C}$ as $29.8 \%$ WPS. It is known that such products are eaten without desalting or cooking. Therefore, such high values are not usually preferred by the consumers. Variations in the levels of salt and WPS were reported for commercially salted lakerda products (Koral et al., 2013). Our results were within the range of the values reported for commercial lakerda products both from Greece and Turkey (Koral et al., 2013).

Water activity $\left(a_{w}\right)$ is another growth limiting factor for microorganisms. Salting decreases $\mathrm{a}_{\mathrm{w}}$ and has inhibition effect on pathogenic bacteria. According to FDA guideline (FDA, 2011 ), minimum $\mathrm{a}_{\mathrm{w}}$ to allow the growth of $S$. aureus is 0.83 and toxin formation is 0.85 using salt. Water activity of fresh Atlantic bonito was 0.994 . The $\mathrm{a}_{\mathrm{w}}$ values significantly $(\mathrm{p}<0.05)$ dropped down to $0.783(\mathrm{~min})$ - 0.885 (max) within the $1^{\text {st }}$ week of storage for all experimental groups (Table 3 ). The $a_{w}$ values were usually found within the safety limit on the $1^{\text {st }}$ week as suggested by FDA to prevent bacteria growth or toxin formation. The results showed that the higher the salt contents, the lower $a_{w}$ values were found. In our previous studies, we determined varying $\mathrm{a}_{\mathrm{w}}$ levels from commercial lakerda produced from Atlantic bonito and other fish products from Turkish and EU origin indicating the variations in the methodology used (Köse et al., 2012; Koral et al., 2013). The $\mathrm{a}_{\mathrm{w}}$ results obtained by Ormanc1 and Colakoglu (2017) supported our findings.

The $\mathrm{pH}$ values of freshly processed raw material were found higher than the products originated from previously frozen raw material in a range of 5.75-7.24 and 5.67-6.12, respectively (Table 3 ). The $\mathrm{pH}$ of fish immediately after being caught was reported to be between 6.0 and 6.5. The fish were acceptable up to a $\mathrm{pH}$ of 6.8 but were considered to be spoiled above a pH of 7.0 (Huss, 1988). This $\mathrm{pH}$ is also used for safety regulations for such products since $\mathrm{pH}$ below 5 is reported to prevent most pathogenic bacteria growth or toxin formation (Köse, 2010; FDA, 2011). The levels of $\mathrm{pH}$ obtained for all groups were above 5 indicating this parameter cannot be used to judge the product safety of lakerda prepared from the salt:fish ratios applied in the current study. Although a significant decrease occurred during storage in the $\mathrm{pH}$ values of products originated from frozen raw material $(p<0.05)$, the changes were usually found insignificant $(p>0.05)$ for fresh raw material group with the exception of samples representing 1/6 group stored at ambient temperature starting from $6^{\text {th }}$ week. This result indicates that spoilage is possible at low salt contents at warm temperatures. 
The highest $\mathrm{pH}$ value was obtained as 7.4 at the end of storage period for lakerda produced from fresh raw material using 1/6 ratio and stored at ambient temperature. This group also corresponded to the lowest sensory values (Table 4). The $\mathrm{pH}$ values obtained by Ormanc1 and Colakoglu (2017) supported our findings.

Table 4 and the figures 2 and 3 represent sensory scores of lakerda processed from fresh and frozen Atlantic bonito. The results for texture, odour and appearance of the samples showed that the products with the lowest salt content had the lowest sensory acceptance (Table 4). Significant differences $(\mathrm{p}<0.05)$ occurred amongst all groups relating to all sensory parameters tested throughout the storage. The sensory scores decreased significantly during time depending on the ratios of salt:fish used (Figure 2 and 3 ). The products corresponding to $1 / 3$ and $1 / 4$ salt:fish ratio groups were within the good quality throughout the storage period indicating the suitability of these salt ratios for lakerda production for both raw material and storage temperature groups. However, at ambient temperature, the samples corresponded to $1 / 6$ salt:fish ratio group were unacceptable after $1^{\text {st }}$ month of storage according to sensory scores for both types of raw material used. The cold storage prolonged shelf-life of these products at refrigerated temperature particularly for the group obtained from previously frozen raw materials.It is also noted that sensory scores of lakerda processed from previously frozen Atlantic bonito were higher than freshly processed Atlantic bonito with the exception of salting group of $1 / 6$ stored at ambient temperature $\left(17 \pm 3^{\circ} \mathrm{C}\right)$. The products obtained with frozen raw materials and then kept at refrigerated temperatures were in acceptable quality throughout storage period for all types of salting groups. Therefore, the results suggest that freezing raw material prior to processing and refrigeration after processing is necessary if longer shelf life is required. Such advantage is more profound for the lowest salt:fish ration at refrigerated storage since the products were within acceptable quality at the end of 3 months' storage while being unacceptable for freshly processed group at the end of $2^{\text {nd }}$ month.

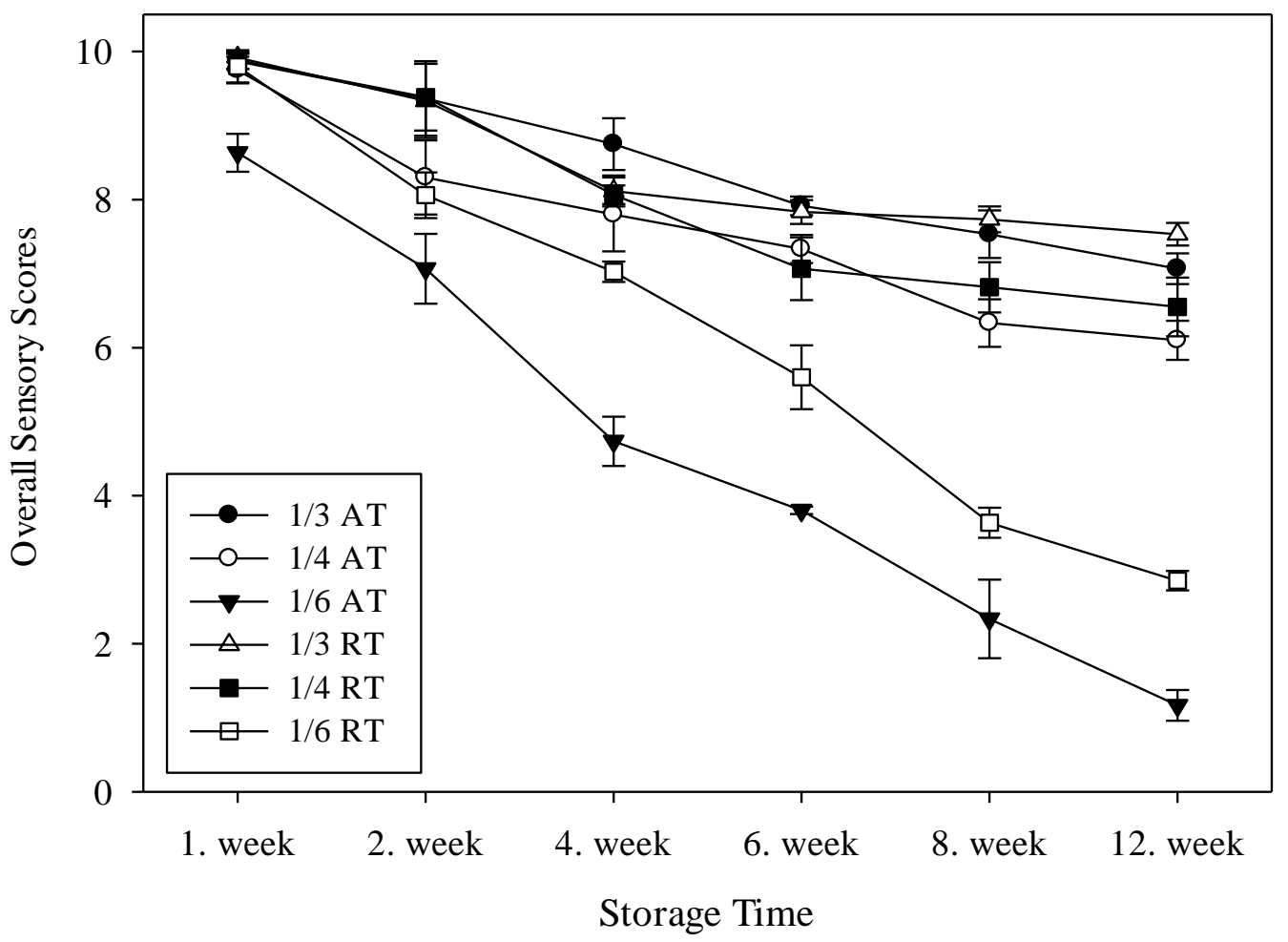

Figure 2. Overall sensory scores for lakerda (dry salted Atlantic bonito) processed from fresh raw materials, stored at ambient $\left(17 \pm 3^{\circ} \mathrm{C}\right)$ and refrigerated $\left(4 \pm 1^{\circ} \mathrm{C}\right)$ temperatures 


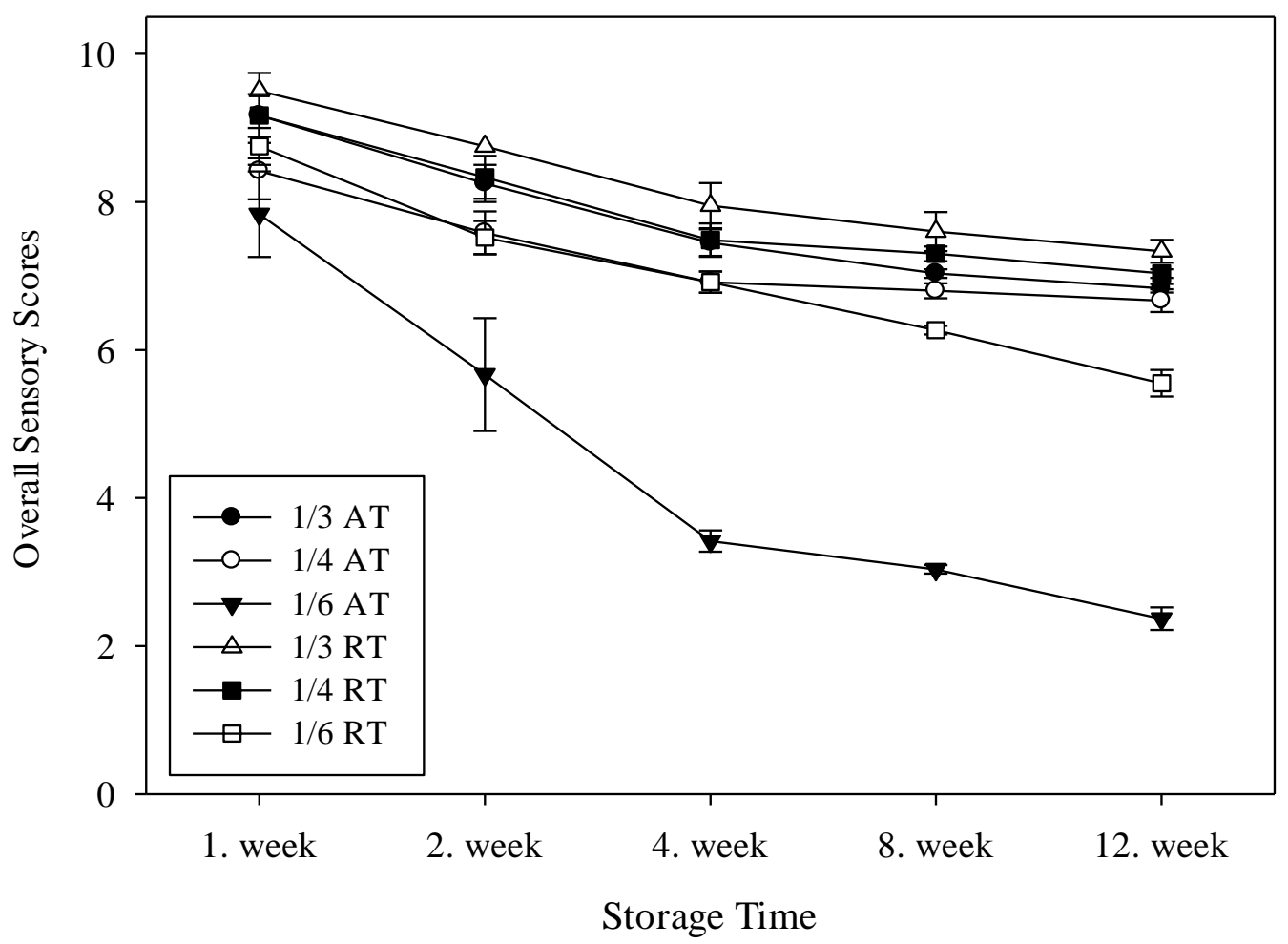

\section{AT: Ambient temperature, RT: Refrigerated temperature}

Figure 3. Overall sensory scores for lakerda (dry salted Atlantic bonito) processed from previously frozen raw materials, stored at ambient $\left(17 \pm 3^{\circ} \mathrm{C}\right)$ and refrigerated $\left(4 \pm 1^{\circ} \mathrm{C}\right)$ temperatures

Different studies reported different shelf lives for lakerda depending on the storage temperature, and processing and/or packaging methods. Our results obtained for the samples stored at refrigerated conditions supported the results reported by Erkan et al. (2009) for brine, vacuum- and oilpacked lakerda samples produced from Atlantic bonito stored at the same conditions. The amount of salt used prior to brining in their study was higher than the present study. Therefore, the present study suggests that salt:fish ratio higher than 1:3 may not add beneficial effect to the sensory life of lakerda although the shelf-life can also be affected by the different production methodology in two different studies. Lüleci (1991) obtained 60 days of shelf-life for lakerda made from Atlantic bonito stored in brine at $4{ }^{\circ} \mathrm{C}$. Recently, Caglak et al. (2016) reported a very short shelf-life for lakerda at refrigerated storage packed in plastic bags as less than 8 days. They reported that vacuum and modified atmosphere packing extended the shelf-life up to 23 days. Although their method is similar to the current study in terms of dry salting at the beginning, later they used brine solution for maturation which differs from the present study. Therefore, the amount of salt used is not very clear which makes it difficult to compare with the current study. Turan et al. (2006) and recently, Kocatepe et al. (2014) also investigated shelf-life of dry salted Atlantic bonito which was processed as lakerda at refrigerated storage. However, both studies did not determined the sensory values, and the shelf stability of the products was judged using chemical and microbiological quality. Such results can only be evaluated in support of sensory values. In our previous study, we observed 4 days of shelf life for hot-smoked Atlantic bonito at ambient temperature $\left(17 \pm 3^{\circ} \mathrm{C}\right)$, and 10 days at refrigerated temperature (Koral et al., 2010). Therefore, lakerda has an advantage over such products in terms of extending the shelf-life of this species.

The results of TVB-N, TMA and TBA are shown in Table 5 . The TVB-N values increased significantly $(p<0.05)$ for all groups throughout the storage, and also significant differences $(p<0.05)$ were observed amongst different salting and storage groups with some exceptions. Varying levels of TVB-N have been suggested for different fish products to assess their freshness in literature (Connell, 1990; Huss, 1988). European Union set varying TVB-N limits as 25-35 $\mathrm{mg} / 100 \mathrm{~g}$ for unprocessed fishery products shall be regarded 
as unfit for human consumption where organoleptic assessment has raised doubts as to their freshness (EU Directive, 2005b and 2008). However, Atlantic bonito is not included in EU regulation. Therefore, TVB-N levels can be used only in support of sensory values. Our results showed that TVB$\mathrm{N}$ did not support sensory values (Table 5). TVB-N values of the lowest salt concentration group reached to the unacceptable level set by EU regulation on the $4^{\text {th }}$ week for each raw material group stored at ambient temperatures $\left(17 \pm 3^{\circ} \mathrm{C}\right)$. The TVB-N values were within the permitted level (min: $18.21 \mathrm{mg} / 100 \mathrm{~g}$-max: $22.06 \mathrm{mg} / 100 \mathrm{~g}$ ) for other groups. Therefore, the results shows the advantage of refrigerated storage for keeping better chemical quality of dry salted Atlantic bonito. Lower TVB-N values were obtained by Erkan et al.(2009) and Kocatepe et al.(2014), while TVB-N levels reported by Turan et al.(2006) were close to some of our experimental groups. The TVB-N levels in fisheries products are affected by different factors including the initial condition of the fish which explains the differences in the different studies (Huss, 1988).

TBA values increased significantly throughout storage $(p<0.05)$. There was also significant differences $(p<0.05)$ amongst the groups with some exceptions. TBA is a quality parameter particularly relates to lipid oxidation. The lowest TBA value was found with the products originated from frozen raw material and treated with the lowest salt content $(1 / 6$ salt:fish ratio). The products treated with $1 / 3$ salt:fish ratio and kept at ambient temperature reached to unacceptable level at the end of storage for freshly processed Atlantic bonito. Therefore, this study indicates that high salt content can accelerate lipid oxidation, while freezing and frozen storage to prior to salting can retard oxidative changes in fish products. Erkan et al. (2009) reported a decrease in TBA values during storage of lakerda from Atlantic bonito at refrigerated temperatures with some fluctuations. Therefore, their results did not support our findings. Kocatepe et al. (2014) observed higher TBA contents. The differences may have caused due to differences in processing stages and the initial condition of the fish prior to processing.

Trimethylamine values of lakerda showed similar trend with TVB-N values. The highest TMA values were found in the products treated with the lowest salt concentration and kept at ambient temperature $\left(17 \pm 3^{\circ} \mathrm{C}\right)$. At the end of storage, TMA values were 10.72 and $11.12 \mathrm{mg} / 100 \mathrm{~g}$ for fresh and frozen raw material groups, respectively. Significant differences $(p<0.05)$ were found during storage and amongst the groups. TMA is another chemical parameter commonly used to determine fish spoilage. It is a pungent volatile amine often associated with the typical "fishy" odour of spoiling seafood. Its presence in spoiling fish is due to the bacterial reduction of trimethylamine oxide which is naturally present in the living tissue of many marine fish species. Although TMA is believed to be generated by the action of spoilage bacteria, the correlation with bacterial numbers is often not very good (Huss, 1995). A suggested acceptable level is reported as $12 \mathrm{mg} / 100 \mathrm{~g}$ (Goulas and Kontominos, 2005). TMA values were still below the suggested upper limit for this parameter. The results of Turan et al.(2006) and Erkan et al.(2009) supported our values for some experimental groups.

Table 6 and 7 show the changes in the biogenic amine values of dry salted Atlantic bonito (lakerda) during storage. The results of the conducted study showed that dry salting prevents the formation of biogenic amines, particularly histamine. The levels of histamine were below 29 ppm throughout the storage despite of differences in the groups of salt:fish ratio and storage temperatures. This study also showed that although spermidine levels of fresh and processed Atlantic bonito were higher at the beginning of storage, it generally decreased until the end of storage for all types of samples. The highest biogenic amine values corresponded to Atlantic bonito treated with the ratio of $1 / 6$ salt:fish content stored at ambient temperature. Therefore, the results demonstrated the beneficial effect of high salt concentration and refrigeration on preventing histamine formation in salted Atlantic bonito. Histamine values were also found very low and none of the products exceeded the permitted levels set by FDA, EU and Turkish authorities.

Ormanc1 and Colakoglu (2017) reported that all biogenic amines analysed decreased significantly $(p<0.05)$ during ripening of lakerda from Atlantic bonito with the exception of spermine at both refrigerated and ambient temperatures. However, they also obtained an increase for most biogenic amines at different days depending on the ripening temperatures. Although initial histamine value in fresh fish used in their study was higher than the value obtained in present study, lower histamine contents were recorded by the authors for the samples ripened at both 17 and $20^{\circ} \mathrm{C}$. Histamine formation can be affected by various factors. 
Table 1. The changes in the contents of dry matter (\%) of lakerda (dry salted Atlantic bonito) processed from fresh and previously frozen raw materials, stored at ambient $\left(17 \pm 3^{\circ} \mathrm{C}\right)$ and refrigerated $\left(4 \pm 1^{\circ} \mathrm{C}\right)$ temperatures.

\begin{tabular}{|c|c|c|c|c|c|c|c|c|c|}
\hline $\mathbf{R M}$ & ST & SFR & Fresh bonito & $\mathbf{1}^{\text {st }}$ week & $2^{\text {nd }}$ week & $4^{\text {th }}$ week & $6^{\text {th }}$ week & $8^{\text {th }}$ week & $12^{\text {th }}$ week \\
\hline \multirow{6}{*}{ 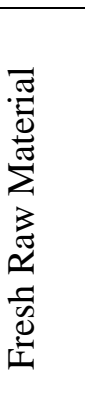 } & \multirow{5}{*}{ AT } & $1 / 3$ & \multirow{6}{*}{$36.86 \pm 0.28$} & $* 53.14 \pm 0.17^{\mathrm{c}} \mathrm{A}$ & $53.33 \pm 0.55^{\mathrm{c}}{ }_{\mathrm{A}}$ & $* 54.58 \pm 0.44_{\mathrm{A}}^{\mathrm{d}}$ & $53.67 \pm 0.48^{\mathrm{d}}{ }_{\mathrm{A}}$ & $53.91 \pm 0.03_{\mathrm{A}}^{\mathrm{c}}$ & $* 51.69 \pm 0.49^{c}{ }_{B}$ \\
\hline & & $1 / 4$ & & $50.58 \pm 0.53^{\mathrm{b}}{ }_{\mathrm{A}}$ & $52.13 \pm 0.08^{\mathrm{c}}{ }_{\mathrm{A}}$ & $* 51.99 \pm 0.67^{\mathrm{c}} \mathrm{A}$ & $52.09 \pm 0.68_{\mathrm{A}}^{\mathrm{c}}$ & $* 50.98 \pm 1.62^{\mathrm{b}} \mathrm{A}$ & $* 49.55 \pm 0.62^{\mathrm{b}}{ }_{\mathrm{A}}$ \\
\hline & & $1 / 6$ & & $* 44.86 \pm 0.72^{\mathrm{a}} \mathrm{A}$ & $* 47.30 \pm 0.23^{\mathrm{a}}{ }_{\mathrm{B}}$ & $* 48.98 \pm 0.28^{\mathrm{b}}{ }_{\mathrm{B}}$ & $48.98 \pm 0.22^{\mathrm{b}}{ }_{\mathrm{B}}$ & $* 48.64 \pm 0.52^{\mathrm{b}}{ }_{\mathrm{B}}$ & $* 46.03 \pm 0.48^{\mathrm{a}}{ }_{\mathrm{C}}$ \\
\hline & & $1 / 3$ & & $52.13 \pm 0.35^{\mathrm{c}} \mathrm{A}$ & $53.14 \pm 0.21^{\mathrm{c}}{ }_{\mathrm{B}}$ & $* 53.09 \pm 0.55^{\mathrm{d}}{ }_{\mathrm{B}}$ & $53.22 \pm 0.12^{\mathrm{d}}{ }_{\mathrm{B}}$ & $52.88 \pm 0.34^{\mathrm{c}}{ }_{\mathrm{B}}$ & $54.98 \pm 1.32^{\mathrm{d}}{ }_{\mathrm{B}}$ \\
\hline & & $1 / 4$ & & $* 50.99 \pm 0.51^{\mathrm{b}} \mathrm{A}$ & $50.66 \pm 0.50^{\mathrm{b}}{ }_{\mathrm{A}}$ & $* 50.94 \pm 0.18^{\mathrm{c}} \mathrm{A}$ & $51.10 \pm 0.86^{\mathrm{c}} \mathrm{A}$ & $52.88 \pm 0.34^{\mathrm{c}}{ }_{\mathrm{B}}$ & $52.69 \pm 0.26^{\mathrm{c}}{ }_{\mathrm{A}}$ \\
\hline & RT & $1 / 6$ & & $45.42 \pm 0.65^{\mathrm{a}} \mathrm{A}$ & $* 46.37 \pm 0.21^{\mathrm{a}} \mathrm{A}$ & $* 46.49 \pm 0.18^{\mathrm{a}} \mathrm{A}$ & $47.01 \pm 0.35^{\mathrm{a}} \mathrm{A}$ & $* 45.91 \pm 0.22^{\mathrm{a}} \mathrm{A}$ & $* 48.22 \pm 0.16^{\mathrm{b}}{ }_{\mathrm{B}}$ \\
\hline \multirow{6}{*}{ 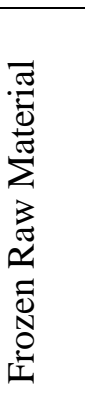 } & & $1 / 3$ & \multirow{6}{*}{$37.22 \pm 0.26$} & $* 54.87 \pm 0.25^{\mathrm{d}} \mathrm{A}$ & $55.35 \pm 0.82^{\mathrm{d}} \mathrm{A}$ & $* 57.09 \pm 1.38_{\mathrm{A}}^{\mathrm{d}}$ & NA & $54.88 \pm 1.22^{\mathrm{b}}{ }_{\mathrm{A}}$ & $* 55.52 \pm 0.38^{\mathrm{d}}{ }_{\mathrm{A}}$ \\
\hline & & $1 / 4$ & & $51.14 \pm 0.40^{\mathrm{c}}{ }_{\mathrm{A}}$ & $51.83 \pm 0.71^{\mathrm{bc}} \mathrm{A}$ & $* 54.54 \pm 0.25^{\mathrm{c}} \mathrm{A}$ & NA & $* 53.46 \pm 0.86_{\mathrm{A}}^{\mathrm{b}}$ & $* 53.65 \pm 0.15^{\mathrm{c}} \mathrm{A}$ \\
\hline & AT & $1 / 6$ & & $* 47.87 \pm 0.21_{\mathrm{A}}^{\mathrm{b}}$ & $* 50.33 \pm 0.38^{b}{ }_{B}$ & $* 51.89 \pm 0.84^{\mathrm{b}}{ }_{\mathrm{B}}$ & NA & $* 52.95 \pm 1.09^{\mathrm{b}}{ }_{\mathrm{B}}$ & $* 52.80 \pm 0.44^{\mathrm{b}}{ }_{\mathrm{B}}$ \\
\hline & & $1 / 3$ & & $51.86 \pm 0.80^{\mathrm{c}}{ }_{\mathrm{A}}$ & $52.76 \pm 0.52^{\mathrm{c}}{ }_{\mathrm{A}}$ & $* 55.14 \pm 0.22^{c}{ }_{B}$ & NA & $53.80 \pm 0.28^{\mathrm{b}} \mathrm{A}$ & $53.58 \pm 0.12^{\mathrm{c}}{ }_{\mathrm{A}}$ \\
\hline & & $1 / 4$ & & $* 46.26 \pm 0.37^{\mathrm{b}} \mathrm{A}$ & $51.21 \pm 0.11^{\mathrm{b}}{ }_{\mathrm{B}}$ & $* 52.21 \pm 0.02^{\mathrm{b}}{ }_{\mathrm{B}}$ & NA & $49.44 \pm 0.25^{\mathrm{a}}{ }_{\mathrm{B}}$ & $52.01 \pm 0.32^{\mathrm{b}}{ }_{\mathrm{B}}$ \\
\hline & RT & $1 / 6$ & & $43.91 \pm 0.82^{\mathrm{a}} \mathrm{A}$ & $* 48.35 \pm 0.64^{\mathrm{a}}{ }_{\mathrm{B}}$ & $* 47.25 \pm 0.20^{\mathrm{a}}{ }_{\mathrm{B}}$ & NA & $* 48.60 \pm 0.15^{\mathrm{a}}{ }_{\mathrm{B}}$ & $* 49.55 \pm 0.28^{\mathrm{a}}{ }_{\mathrm{B}}$ \\
\hline
\end{tabular}

A: Analysis, RW: Raw Material Type, ST: Storage Temperature, SFR: The ratio of salt:fish(w:w), AT: Ambient Temperature, RT: Refrigerated Temperature, NA: Not Analysed, $\pm S D: n: 3$, The different superscript lowercase letters $(a, b, c .$.$) represent statistical differences amongst different salting subgroups under each raw material$ group at the same storage time ( $p<0.05)$. The different subscript uppercase letters $(A, B, C \ldots)$ represents statistical differences during storage period of the same group $(p<0.05)$. '*' on each data represents that there is statistical difference between the data obtained for fresh and frozen raw material groups at the same storage time and the ration of salt:fish 
Table 2. The changes in the contents of salt (\%) and WPS \% of lakerda (dry salted Atlantic bonito) processed from fresh and previously frozen raw materials, stored at ambient $\left(17 \pm 3^{\circ} \mathrm{C}\right)$ and refrigerated $\left(4 \pm 1^{\circ} \mathrm{C}\right)$ temperatures.

\begin{tabular}{|c|c|c|c|c|c|c|c|c|c|c|}
\hline$\overline{\mathbf{A}}$ & $\mathbf{R M}$ & ST & SFR & Fresh & $\begin{array}{ll}1^{\text {st }} \text { week } \\
\end{array}$ & $2^{\text {nd }}$ week & $4^{\text {th }}$ week & $6^{\text {th }}$ week & $8^{\text {th }}$ week & $12^{\text {th }}$ week \\
\hline \multirow{12}{*}{ 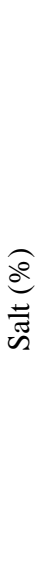 } & \multirow{6}{*}{ 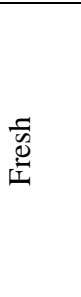 } & AT & $1 / 3$ & \multirow{6}{*}{$0.61 \pm 0.02$} & $16.37 \pm 0.13^{\mathrm{e}} \mathrm{A}$ & $16.42 \pm 0.07^{\mathrm{e}} \mathrm{A}$ & $16.23 \pm 0.11^{\mathrm{e}} \mathrm{A}$ & $17.22 \pm 0.10^{f_{B}}$ & $17.32 \pm 0.06^{\mathrm{e}}{ }_{\mathrm{B}}$ & $16.14 \pm 0.12^{\mathrm{d}} \mathrm{A}$ \\
\hline & & \multirow{5}{*}{ RT } & $1 / 4$ & & $* 15.51 \pm 0.06^{\mathrm{d}} \mathrm{A}$ & $* 15.92 \pm 0.04{ }_{B}^{d_{B}}$ & $* 15.47 \pm 0.05^{\mathrm{d}} \mathrm{A}$ & $15.44 \pm 0.06^{\mathrm{d}}{ }_{\mathrm{A}}$ & $* 15.36 \pm 0.15^{\mathrm{c}} \mathrm{A}$ & $* 15.21 \pm 0.05^{\mathrm{c}} \mathrm{A}$ \\
\hline & & & $1 / 6$ & & $* 11.33 \pm 0.03^{\mathrm{b}} \mathrm{A}$ & $12.31 \pm 0.14^{b_{B}}$ & $13.08 \pm 0.08^{\mathrm{b}} \mathrm{C}$ & $13.24 \pm 0.03^{b} \mathrm{C}$ & $13.60 \pm 0.14^{\mathrm{a}} \mathrm{D}$ & $13.16 \pm 0.10^{\mathrm{a}} \mathrm{C}$ \\
\hline & & & $1 / 3$ & & $* 16.16 \pm 0.05^{\mathrm{e}} \mathrm{A}$ & $16.19 \pm 0.14_{\mathrm{A}}^{\mathrm{e}}$ & $* 16.50 \pm 0.04 \mathrm{f}_{\mathrm{B}}$ & $16.59 \pm 0.08^{\mathrm{e}_{B}}$ & $* 16.32 \pm 0.06^{\mathrm{d}} \mathrm{A}$ & $* 16.05 \pm 0.06^{\mathrm{d}}{ }_{\mathrm{A}}$ \\
\hline & & & $1 / 4$ & & $* 13.17 \pm 0.05^{\mathrm{c}} \mathrm{A}$ & $* 13.77 \pm 0.22^{c_{B}}$ & $* 13.90 \pm 0.03^{\mathrm{c}} \mathrm{B}$ & $14.58 \pm 0.04^{\mathrm{c}} \mathrm{C}$ & $* 14.44 \pm 0.12^{\mathrm{b}} \mathrm{C}$ & $14.04 \pm 0.22^{\mathrm{b}}{ }_{\mathrm{B}}$ \\
\hline & & & $1 / 6$ & & $* 9.61 \pm 0.07^{\mathrm{a}} \mathrm{A}$ & $11.78 \pm 0.10^{\mathrm{a}} \mathrm{B}$ & $* 11.32 \pm 0.09^{\mathrm{a}} \mathrm{C}$ & $12.82 \pm 0.04^{\mathrm{a}} \mathrm{D}$ & $* 13.49 \pm 0.26^{\mathrm{a}} \mathrm{E}$ & $* 13.66 \pm 0.16^{b} \mathrm{E}$ \\
\hline & \multirow{6}{*}{ 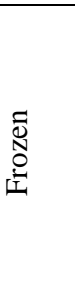 } & AT & $1 / 3$ & \multirow{6}{*}{$0.66 \pm 0.08$} & $16.36 \pm 0.38^{\mathrm{e}} \mathrm{A}$ & $16.38 \pm 0.37^{\mathrm{d}} \mathrm{A}$ & $16.36 \pm 0.21_{\mathrm{A}}^{\mathrm{d}}$ & NA & $16.98 \pm 0.10^{\mathrm{d}} \mathrm{A}$ & $16.33 \pm 0.12^{\mathrm{e}} \mathrm{A}$ \\
\hline & & & $1 / 4$ & & $* 13.89 \pm 0.10^{\mathrm{c}} \mathrm{A}$ & $* 14.49 \pm 0.26^{\mathrm{c}} \mathrm{B}$ & $* 14.68 \pm 0.12^{c_{B}}$ & NA & $* 14.04 \pm 0.18^{\mathrm{b}} \mathrm{A}$ & $* 14.33 \pm 0.42^{c}{ }^{\mathrm{B}}$ \\
\hline & & & $1 / 6$ & & $* 12.68 \pm 0.30^{\mathrm{b}} \mathrm{A}$ & $12.24 \pm 0.11^{\mathrm{b}} \mathrm{A}$ & $13.11 \pm 0.05^{\mathrm{b}} \mathrm{B}$ & NA & $13.16 \pm 0.25^{\mathrm{ab}_{\mathrm{B}}}$ & $13.63 \pm 0.15^{\mathrm{b}} \mathrm{C}$ \\
\hline & & RT & $1 / 3$ & & $* 14.14 \pm 0.10^{\mathrm{d}} \mathrm{A}$ & $* 14.70 \pm 0.08^{c_{B}}$ & $* 14.91 \pm 0.06^{\mathrm{c}}{ }_{\mathrm{B}}$ & NA & $* 15.51 \pm 0.26^{\mathrm{c}} \mathrm{C}$ & $* 15.28 \pm 0.36^{\mathrm{d}}{ }_{\mathrm{BC}}$ \\
\hline & & & $1 / 4$ & & $* 12.19 \pm 0.19^{\mathrm{b}} \mathrm{A}$ & $* 12.45 \pm 0.22^{\mathrm{b}} \mathrm{A}$ & $* 13.03 \pm 0.14^{b_{B}}$ & NA & $* 13.68 \pm 0.34^{\mathrm{b}} \mathrm{C}$ & $13.92 \pm 0.24^{\mathrm{b}} \mathrm{C}$ \\
\hline & & & $1 / 6$ & & $* 10.55 \pm 0.31^{\mathrm{a}} \mathrm{A}$ & $11.41 \pm 0.17^{\mathrm{a}} \mathrm{B}$ & $* 11.99 \pm 0.07^{\mathrm{a}} \mathrm{B}$ & NA & $* 12.69 \pm 0.24^{\mathrm{a}} \mathrm{C}$ & $* 12.57 \pm 0.27^{\mathrm{a}} \mathrm{C}$ \\
\hline \multirow{12}{*}{ 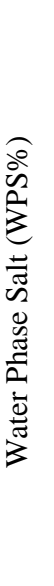 } & \multirow{6}{*}{$\begin{array}{l}\frac{5}{5} \\
\stackrel{0}{\underline{1}}\end{array}$} & AT & $1 / 3$ & \multirow{6}{*}{$0.96 \pm 0.04$} & $25.89 \pm 0.22^{\mathrm{e}} \mathrm{A}$ & $26.03 \pm 0.31^{\mathrm{e}} \mathrm{A}$ & $* 26.33 \pm 0.32^{\mathrm{e}} \mathrm{A}$ & $27.10 \pm 0.32^{\mathrm{f}}$ & $27.31 \pm 0.05^{\mathrm{e}}{ }_{\mathrm{B}}$ & $* 25.04 \pm 0.15^{\mathrm{c}} \mathrm{A}$ \\
\hline & & & $1 / 4$ & & $* 23.88 \pm 0.13^{\mathrm{d}} \mathrm{A}$ & $24.96 \pm 0.02^{\mathrm{d}_{\mathrm{B}}}$ & $24.37 \pm 0.31^{\mathrm{d}}{ }_{\mathrm{A}}$ & $24.37 \pm 0.19^{\mathrm{d}}{ }_{\mathrm{A}}$ & $23.87 \pm 0.42^{\mathrm{d}} \mathrm{A}$ & $* 23.16 \pm 0.12^{\mathrm{b}} \mathrm{A}$ \\
\hline & & & $1 / 6$ & & $* 17.04 \pm 0.14^{\mathrm{b}} \mathrm{A}$ & $* 18.94 \pm 0.11^{\mathrm{b}} \mathrm{B}$ & $20.41 \pm 0.01^{\mathrm{b}}{ }_{\mathrm{C}}$ & $20.61 \pm 0.03^{\mathrm{b}} \mathrm{C}$ & $* 20.94 \pm 0.34^{b} \mathrm{C}$ & $* 19.60 \pm 0.24^{\mathrm{a}} \mathrm{C}$ \\
\hline & & RT & $1 / 3$ & & $* 25.24 \pm 0.19^{\mathrm{e}} \mathrm{A}$ & $25.68 \pm 0.24^{\mathrm{e}} \mathrm{A}$ & $* 26.02 \pm 0.18^{\mathrm{e}} \mathrm{A}$ & $26.18 \pm 0.10^{\mathrm{e}} \mathrm{A}$ & $25.73 \pm 0.07^{\mathrm{d}} \mathrm{A}$ & $* 26.28 \pm 0.17^{\mathrm{d}} \mathrm{A}$ \\
\hline & & & $1 / 4$ & & $* 21.18 \pm 0.11^{\mathrm{c}} \mathrm{A}$ & $21.82 \pm 0.20^{\mathrm{c}} \mathrm{A}$ & $* 22.08 \pm 0.06^{\mathrm{c}} \mathrm{A}$ & $22.97 \pm 0.36^{\mathrm{c}} \mathrm{B}$ & $* 22.69 \pm 0.17^{c_{B}}$ & $22.88 \pm 0.10^{\mathrm{b}}{ }_{\mathrm{B}}$ \\
\hline & & & $1 / 6$ & & $* 14.97 \pm 0.25^{\mathrm{a}} \mathrm{A}$ & $18.01 \pm 0.12^{\mathrm{a}} \mathrm{B}$ & $* 17.46 \pm 0.16^{\mathrm{a}} \mathrm{C}$ & $19.48 \pm 0.06^{\mathrm{a}} \mathrm{D}$ & $19.95 \pm 0.24^{\mathrm{a}} \mathrm{D}$ & $* 20.87 \pm 0.16^{\mathrm{a}} \mathrm{E}$ \\
\hline & \multirow{6}{*}{ 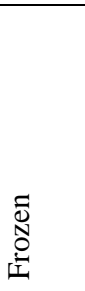 } & AT & $1 / 3$ & \multirow{6}{*}{$1.04 \pm 0.04$} & $26.60 \pm 0.34^{\mathrm{d}} \mathrm{A}$ & $26.84 \pm 0.09^{\mathrm{d}} \mathrm{A}$ & $* 27.61 \pm 0.39^{d}$ & NA & $27.34 \pm 0.24^{\mathrm{e}_{\mathrm{B}}}$ & $* 26.85 \pm 0.32^{\mathrm{e}} \mathrm{A}$ \\
\hline & & & $1 / 4$ & & $* 22.13 \pm 0.26^{\mathrm{c}} \mathrm{A}$ & $23.12 \pm 0.58^{\mathrm{c}} \mathrm{A}$ & $24.41 \pm 0.05^{\mathrm{c}} \mathrm{B}$ & NA & $23.17 \pm 0.15^{\mathrm{c}} \mathrm{A}$ & $* 23.61 \pm 0.25^{\mathrm{c}} \mathrm{A}$ \\
\hline & & & $1 / 6$ & & $* 19.57 \pm 0.44_{\mathrm{A}}^{\mathrm{b}}$ & $* 19.77 \pm 0.02^{\mathrm{b}}{ }_{\mathrm{A}}$ & $21.41 \pm 0.36^{\mathrm{b}}{ }_{\mathrm{B}}$ & NA & $* 21.85 \pm 0.16^{\mathrm{b}}{ }^{\mathrm{b}}$ & $* 22.40 \pm 0.16^{\mathrm{b}} \mathrm{C}$ \\
\hline & & RT & $1 / 3$ & & $* 22.70 \pm 0.41^{\mathrm{c}} \mathrm{A}$ & $* 23.74 \pm 0.10^{c_{B}}$ & $* 24.95 \pm 0.02^{\mathrm{c}} \mathrm{C}$ & NA & $25.13 \pm 0.12^{\mathrm{d}} \mathrm{C}$ & $* 24.76 \pm 0.12^{\mathrm{d}} \mathrm{C}$ \\
\hline & & & $1 / 4$ & & $* 18.48 \pm 0.14^{\mathrm{b}} \mathrm{A}$ & $20.33 \pm 0.25^{\mathrm{b}} \mathrm{B}$ & $* 21.42 \pm 0.17^{b} \mathrm{C}$ & NA & $* 21.29 \pm 0.16^{\mathrm{b}} \mathrm{C}$ & $22.48 \pm 0.14^{\mathrm{b}} \mathrm{D}$ \\
\hline & & & $1 / 6$ & & $* 15.83 \pm 0.20^{\mathrm{a}} \mathrm{A}$ & $18.09 \pm 0.04^{\mathrm{a}} \mathrm{B}$ & $* 18.52 \pm 0.03^{\mathrm{a}} \mathrm{B}$ & NA & $19.80 \pm 0.32^{\mathrm{a}} \mathrm{C}$ & $* 19.94 \pm 0.08^{\mathrm{a}} \mathrm{C}$ \\
\hline
\end{tabular}

A: Analysis, RW: Raw Material Type, ST: Storage Temperature, SFR: The ratio of salt:fish( $w: w)$, AT: Ambient Temperature, RT: Refrigerated Temperature, NA: Not Analysed, \pm SD: $n: 3$, The different superscript lowercase letters $(a, b, c$. ) represent statistical differences amongst different salting subgroups under each raw material group at the same storage time ( $<<0.05)$. The different subscript uppercase letters $(A, B, C \ldots)$ represents statistical differences during storage period of the same group ( $p<0.05)$. '*' on each data represents that there is statistical difference between the data obtained for fresh and frozen raw material groups at the same storage time and the ration of salt:fish. 
Table 3. The changes in the contents of $\mathrm{pH}$ and water activity $\left(\mathrm{a}_{\mathrm{w}}\right)$ of lakerda (dry salted Atlantic bonito) processed from fresh and previously frozen raw materials, stored at ambient $\left(17 \pm 3^{\circ} \mathrm{C}\right)$ and refrigerated $\left(4 \pm 1^{\circ} \mathrm{C}\right)$ temperatures

\begin{tabular}{|c|c|c|c|c|c|c|c|c|c|c|}
\hline $\mathbf{A}$ & $\mathbf{R M}$ & ST & SFR & $\begin{array}{c}\text { Fresh } \\
\text { Bonito }\end{array}$ & $1^{\text {st }}$ week & $2^{\text {nd }}$ week & $4^{\text {th }}$ week & $6^{\text {th }}$ week & $8^{\text {th }}$ week & $12^{\text {th }}$ week \\
\hline \multirow{12}{*}{ 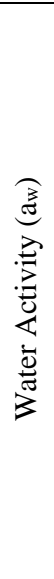 } & \multirow{6}{*}{ 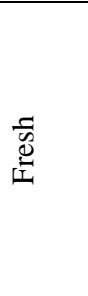 } & AT & $1 / 3$ & \multirow{6}{*}{$\begin{array}{c}0.994 \\
\pm 0.001\end{array}$} & $* 0.753 \pm 0.001^{\mathrm{a}} \mathrm{A}$ & $* 0.760 \pm 0.0011^{\mathrm{a}} \mathrm{B}$ & $0.753 \pm 0.001^{\mathrm{a}} \mathrm{A}$ & $0.756 \pm 0.001^{\mathrm{a}} \mathrm{C}$ & $* 0.747 \pm 0.001^{\mathrm{a}} \mathrm{D}$ & $0.749 \pm 0.001^{\mathrm{b}} \mathrm{D}$ \\
\hline & & & $1 / 4$ & & $* 0.867 \pm 0.001_{\mathrm{A}}^{\mathrm{f}}$ & $* 0.789 \pm 0.001^{\mathrm{b}}{ }_{\mathrm{B}}$ & $* 0.766 \pm 0.001^{\mathrm{b}} \mathrm{C}$ & $0.769 \pm 0.001^{\mathrm{b}} \mathrm{C}$ & $* 0.756 \pm 0.001^{\mathrm{b}}{ }_{\mathrm{D}}$ & $0.750 \pm 0.001^{\mathrm{b}} \mathrm{E}$ \\
\hline & & & $1 / 6$ & & $* 0.809 \pm 0.001^{\mathrm{c}} \mathrm{A}$ & $* 0.861 \pm 0.001{ }^{\mathrm{e}_{\mathrm{B}}}$ & $* 0.843 \pm 0.001^{\mathrm{f}} \mathrm{C}$ & $0.831 \pm 0.001^{\mathrm{e}} \mathrm{D}$ & $* 0.863 \pm 0.001^{\mathrm{f}} \mathrm{B}$ & $* 0.860 \pm 0.001^{\mathrm{c}} \mathrm{B}$ \\
\hline & & RT & $1 / 3$ & & $* 0.783 \pm 0.000^{\mathrm{b}} \mathrm{A}$ & $* 0.788 \pm 0.000^{\mathrm{b}}{ }_{\mathrm{B}}$ & $* 0.774 \pm 0.001^{\mathrm{c}} \mathrm{C}$ & $0.770 \pm 0.001^{\mathrm{b}} \mathrm{C}$ & $* 0.766 \pm 0.001^{\mathrm{c}} \mathrm{D}$ & $0.746 \pm 0.001^{\mathrm{a}} \mathrm{E}$ \\
\hline & & & $1 / 4$ & & $* 0.815 \pm 0.000^{\mathrm{d}} \mathrm{A}$ & $* 0.807 \pm 0.001^{\mathrm{c}} \mathrm{B}$ & $* 0.785 \pm 0.001^{\mathrm{d}} \mathrm{C}$ & $0.772 \pm 0.002^{\mathrm{b}} \mathrm{D}$ & $* 0.777 \pm 0.000^{\mathrm{d}} \mathrm{E}$ & $0.751 \pm 0.002^{\mathrm{b}} \mathrm{F}$ \\
\hline & & & $1 / 6$ & & $* 0.861 \pm 0.000^{\mathrm{e}} \mathrm{A}$ & $* 0.842 \pm 0.000^{\mathrm{d}_{\mathrm{B}}}$ & $* 0.819 \pm 0.001^{\mathrm{e}} \mathrm{C}$ & $0.812 \pm 0.001^{\mathrm{d}} \mathrm{D}$ & $* 0.840 \pm 0.001^{\mathrm{e}_{\mathrm{B}}}$ & $* 0.817 \pm 0.001^{\mathrm{d}} \mathrm{C}$ \\
\hline & \multirow{6}{*}{ 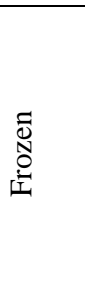 } & AT & $1 / 3$ & \multirow{6}{*}{$\begin{array}{c}0.992 \\
\pm 0.001\end{array}$} & $* 0.765 \pm 0.001^{\mathrm{a}} \mathrm{A}$ & $* 0.755 \pm 0.001^{\mathrm{a}} \mathrm{B}$ & $0.751 \pm 0.001^{\mathrm{a}} \mathrm{C}$ & NA & $* 0.754 \pm 0.001^{b}{ }_{B}$ & $0.749 \pm 0.001^{\mathrm{a}} \mathrm{C}$ \\
\hline & & & $1 / 4$ & & $* 0.790 \pm 0.001^{\mathrm{b}} \mathrm{A}$ & $* 0.778 \pm 0.001^{\mathrm{b}}{ }_{\mathrm{B}}$ & $* 0.753 \pm 0.001^{\mathrm{a}} \mathrm{C}$ & NA & $* 0.760 \pm 0.001^{\mathrm{c}} \mathrm{D}$ & $0.750 \pm 0.001^{\mathrm{a}} \mathrm{C}$ \\
\hline & & & $1 / 6$ & & $* 0.834 \pm 0.002^{\mathrm{d}} \mathrm{A}$ & $* 0.819 \pm 0.001^{\mathrm{d}}{ }_{\mathrm{B}}$ & $* 0.787 \pm 0.002^{\mathrm{d}} \mathrm{C}$ & NA & $* 0.781 \pm 0.002^{\mathrm{e}^{\mathrm{e}}}$ & $* 0.780 \pm 0.002^{\mathrm{d}} \mathrm{D}$ \\
\hline & & RT & $1 / 3$ & & $* 0.819 \pm 0.001^{\mathrm{c}} \mathrm{A}$ & $* 0.777 \pm 0.001^{\mathrm{b}}{ }_{\mathrm{B}}$ & $* 0.761 \pm 0.001^{\mathrm{b}} \mathrm{C}$ & NA & $* 0.751 \pm 0.001^{\mathrm{a}} \mathrm{D}$ & $0.749 \pm 0.001^{\mathrm{a}} \mathrm{D}$ \\
\hline & & & $1 / 4$ & & $* 0.855 \pm 0.001^{\mathrm{e}} \mathrm{A}$ & $* 0.850 \pm 0.002^{\mathrm{e}}{ }_{\mathrm{B}}$ & $* 0.766 \pm 0.001^{\mathrm{c}} \mathrm{C}$ & NA & $* 0.758 \pm 0.001^{\mathrm{c}} \mathrm{D}$ & $0.754 \pm 0.001^{\mathrm{b}} \mathrm{E}$ \\
\hline & & & $1 / 6$ & & $* 0.885 \pm 0.005^{\mathrm{f}} \mathrm{A}$ & $* 0.813 \pm 0.001^{\mathrm{c}} \mathrm{B}$ & $* 0.791 \pm 0.001^{\mathrm{d}} \mathrm{C}$ & NA & $* 0.770 \pm 0.001^{\mathrm{d}} \mathrm{D}$ & $* 0.765 \pm 0.001^{\mathrm{c}} \mathrm{E}$ \\
\hline \multirow{12}{*}{$\stackrel{T}{2}$} & \multirow{6}{*}{ 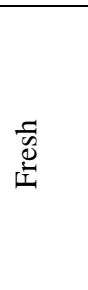 } & AT & $1 / 3$ & \multirow{6}{*}{$\begin{array}{c}6.16 \\
\pm 0.02\end{array}$} & $* 5.83 \pm 0.01^{\mathrm{a}} \mathrm{A}$ & $* 5.95 \pm 0.02^{\mathrm{a}} \mathrm{B}$ & $* 5.93 \pm 0.01^{\mathrm{a}} \mathrm{B}$ & $5.67 \pm 0.01^{\mathrm{a}} \mathrm{C}$ & $5.75 \pm 0.01^{\mathrm{a}} \mathrm{D}$ & $5.83 \pm 0.02^{\mathrm{a}} \mathrm{A}$ \\
\hline & & \multirow{5}{*}{ RT } & $1 / 4$ & & $* 5.90 \pm 0.01^{\mathrm{b}} \mathrm{A}$ & $6.07 \pm 0.01^{\mathrm{b}} \mathrm{B}$ & $* 5.94 \pm 0.01^{\mathrm{a}} \mathrm{C}$ & $5.76 \pm 0.02^{\mathrm{b}} \mathrm{D}$ & $* 5.88 \pm 0.01^{\mathrm{b}} \mathrm{A}$ & $5.85 \pm 0.01^{\mathrm{a}} \mathrm{E}$ \\
\hline & & & $1 / 6$ & & $6.07 \pm 0.01^{\mathrm{d}} \mathrm{A}$ & $* 6.05 \pm 0.03^{\mathrm{b}} \mathrm{A}$ & $* 6.03 \pm 0.02^{\mathrm{b}} \mathrm{AB}$ & $5.97 \pm 0.02^{\mathrm{d}_{\mathrm{B}}}$ & $* 6.30 \pm 0.01^{\mathrm{d}} \mathrm{C}$ & $* 7.24 \pm 0.03^{\mathrm{c}} \mathrm{D}$ \\
\hline & & & $1 / 3$ & & $5.94 \pm 0.01^{\mathrm{c}} \mathrm{A}$ & $* 5.98 \pm 0.02^{\mathrm{a}} \mathrm{A}$ & $* 5.96 \pm 0.01^{\mathrm{a}} \mathrm{A}$ & $5.88 \pm 0.01^{\mathrm{c}_{\mathrm{B}}}$ & $* 5.89 \pm 0.01^{\mathrm{b}}{ }_{\mathrm{B}}$ & $5.83 \pm 0.01^{\mathrm{a}} \mathrm{C}$ \\
\hline & & & $1 / 4$ & & $* 5.86 \pm 0.01^{\mathrm{a}} \mathrm{A}$ & $* 6.04 \pm 0.02^{\mathrm{b}}$ в & $* 6.01 \pm 0.02^{\mathrm{b}}$ в & $5.92 \pm 0.02^{\mathrm{d}} \mathrm{C}$ & $* 5.90 \pm 0.03^{\mathrm{b}} \mathrm{C}$ & $* 5.96 \pm 0.03^{\mathrm{b}} \mathrm{C}$ \\
\hline & & & $1 / 6$ & & $5.98 \pm 0.01^{\mathrm{c}} \mathrm{A}$ & $* 6.10 \pm 0.02^{b}{ }_{B}$ & $* 6.06 \pm 0.02^{\mathrm{b}}{ }_{\mathrm{B}}$ & $5.95 \pm 0.03^{\mathrm{d}}{ }_{\mathrm{A}}$ & $* 5.96 \pm 0.01^{\mathrm{c}} \mathrm{A}$ & $* 5.95 \pm 0.01^{\mathrm{b}}$ \\
\hline & \multirow{6}{*}{ 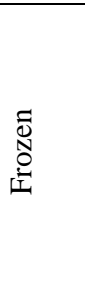 } & AT & $1 / 3$ & \multirow{6}{*}{$\begin{array}{c}6.12 \\
\pm 0.04\end{array}$} & $* 5.92 \pm 0.01^{\mathrm{a}} \mathrm{A}$ & $* 5.80 \pm 0.00^{\mathrm{b}} \mathrm{B}$ & $* 5.78 \pm 0.02^{\mathrm{a}} \mathrm{B}$ & NA & $5.71 \pm 0.03^{\mathrm{b}} \mathrm{C}$ & $5.80 \pm 0.01^{\mathrm{a}}{ }_{\mathrm{B}}$ \\
\hline & & & $1 / 4$ & & $* 6.03 \pm 0.02^{\mathrm{c}} \mathrm{A}$ & $5.77 \pm 0.01^{\mathrm{a}} \mathrm{B}$ & $* 5.81 \pm 0.01^{\mathrm{a}} \mathrm{B}$ & NA & $* 5.67 \pm 0.01^{\mathrm{a}} \mathrm{C}$ & $5.81 \pm 0.03^{\mathrm{a}}{ }_{\mathrm{B}}$ \\
\hline & & & $1 / 6$ & & $6.05 \pm 0.04^{\mathrm{c}} \mathrm{A}$ & $* 5.89 \pm 0.03{ }^{\mathrm{d}} \mathrm{B}$ & $* 5.85 \pm 0.02^{\mathrm{b}} \mathrm{B}$ & NA & $* 5.81 \pm 0.02^{\mathrm{c}} \mathrm{B}$ & $* 5.82 \pm 0.02^{\mathrm{a}} \mathrm{B}$ \\
\hline & & RT & $1 / 3$ & & $5.97 \pm 0.01^{\mathrm{b}} \mathrm{A}$ & $* 5.77 \pm 0.00^{\mathrm{a}} \mathrm{B}$ & $* 5.88 \pm 0.01^{\mathrm{b}} \mathrm{C}$ & NA & $* 5.79 \pm 0.01^{\mathrm{c}} \mathrm{B}$ & $5.82 \pm 0.01^{\mathrm{a}} \mathrm{B}$ \\
\hline & & & $1 / 4$ & & $* 5.96 \pm 0.01^{\mathrm{b}} \mathrm{A}$ & $* 5.82 \pm 0.01{ }^{\mathrm{b}}{ }_{\mathrm{B}}$ & $* 5.88 \pm 0.03^{\mathrm{bc}} \mathrm{C}$ & NA & $* 5.80 \pm 0.03^{\mathrm{c}}{ }_{\mathrm{B}}$ & $* 5.84 \pm 0.02^{\mathrm{a}} \mathrm{B}$ \\
\hline & & & $1 / 6$ & & $6.00 \pm 0.01^{\mathrm{bc}}$ & $* 5.85 \pm 0.00^{c}{ }_{B}$ & $* 5.91 \pm 0.03^{\mathrm{c}}$ & NA & $* 5.86 \pm 0.03^{c}$ & $* 5.88 \pm 0.03^{\mathrm{a}}$ \\
\hline
\end{tabular}

A: Analysis, RW: Raw Material Type, ST: Storage Temperature, SFR: The ratio of salt:fish(w:w), AT: Ambient Temperature, RT: Refrigerated Temperature, NA: Not Analysed, \pm SD: $n: 3$, The different

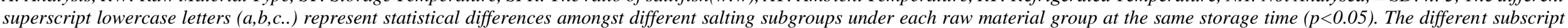

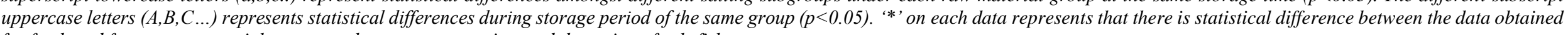
for fresh and frozen raw material groups at the same storage time and the ration of salt:fish. 
Table 4. Sensory scores of lakerda (dry salted Atlantic bonito) processed from fresh and previously frozen raw materials, stored at ambient $\left(17 \pm 3^{\circ} \mathrm{C}\right)$ and refrigerated $\left(4 \pm 1^{\circ} \mathrm{C}\right)$ temperatures.

\begin{tabular}{|c|c|c|c|c|c|c|c|c|c|}
\hline $\mathbf{A}$ & RM & ST & SFR & $1^{\text {st }}$ week & $2^{\text {nd }}$ week & $4^{\text {th }}$ week & $6^{\text {th }}$ week & $8^{\text {th }}$ week & $1^{\text {th }}$ week \\
\hline \multirow{8}{*}{ 兽 } & \multirow{5}{*}{ 竞 } & AT & $1 / 3$ & $9.75 \pm 0.10^{\mathrm{b}}$ & $* 9.30 \pm 0.15^{\mathrm{c}} \mathrm{B}$ & $* 8.35 \pm 0.18^{\mathrm{c}} \mathrm{C}$ & $8.05 \pm 0.06^{\mathrm{d}} \mathrm{C}$ & $* 7.40 \pm 0.05^{\circ} \mathrm{D}$ & $7.00 \pm 0.08^{\mathrm{d}} \mathrm{E}$ \\
\hline & & \multirow{4}{*}{ RT } & $1 / 4$ & $* 9.55 \pm 0.30^{\mathrm{b}}{ }_{\mathrm{A}}$ & $* 8.30 \pm 0.16^{\mathrm{b}}{ }_{\mathrm{B}}$ & $7.30 \pm 0.16^{\mathrm{b}} \mathrm{C}$ & $7.25 \pm 0.23^{\mathrm{c}} \mathrm{C}$ & $* 6.10 \pm 0.06^{c} \mathrm{D}$ & $* 6.00 \pm 0.07^{\mathrm{c}} \mathrm{D}$ \\
\hline & & & $1 / 6$ & $* 8.35 \pm 0.10^{\mathrm{a}}{ }_{\mathrm{A}}$ & $* 7.60 \pm 0.21^{\mathrm{a}} \mathrm{B}$ & $* 4.35 \pm 0.36^{\mathrm{a}} \mathrm{C}$ & $3.80 \pm 0.16^{\mathrm{a}} \mathrm{D}$ & $* 2.25 \pm 0.22^{\mathrm{a}} \mathrm{E}$ & $* 1.10 \pm 0.12^{\mathrm{a}} \mathrm{F}$ \\
\hline & & & $1 / 3$ & $9.85 \pm 0.25^{\mathrm{b}} \mathrm{A}$ & $* 9.15 \pm 0.00^{c_{B}}$ & $8.05 \pm 0.08^{\mathrm{c}} \mathrm{C}$ & $7.65 \pm 0.00^{\mathrm{c}} \mathrm{D}$ & $7.55 \pm 0.34^{\mathrm{e}} \mathrm{D}$ & $7.40 \pm 0.14^{\mathrm{e}} \mathrm{D}$ \\
\hline & & & $1 / 6$ & $* 9.55 \pm 0.05^{\mathrm{b}}{ }_{\mathrm{A}}$ & $* 8.40 \pm 0.20^{\mathrm{b}}{ }_{\mathrm{B}}$ & $7.15 \pm 0.16^{\mathrm{b}} \mathrm{C}$ & $5.10 \pm 0.00^{\mathrm{b}} \mathrm{D}$ & $* 3.40 \pm 0.26^{\mathrm{b}} \mathrm{E}$ & $* 2.80 \pm 0.06^{b}$ \\
\hline & \multirow[b]{3}{*}{ 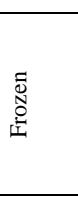 } & $\mathrm{AT}$ & $1 / 3$ & $9.50 \pm 0.50^{\mathrm{b}} \mathrm{A}$ & $* 8.50 \pm 0.50^{\mathrm{c}}{ }_{\mathrm{B}}$ & $* 7.25 \pm 0.25^{\mathrm{b}} \mathrm{C}$ & NA & $* 7.00 \pm 0.15^{\mathrm{c}} \mathrm{C}$ & $6.80 \pm 0.15^{\mathrm{d}} \mathrm{C}$ \\
\hline & & & $1 / 4$ & $* 8.50 \pm 0.50^{\mathrm{b}} \mathrm{A}$ & $* 7.25 \pm 0.25^{\mathrm{a}}{ }_{\mathrm{B}}$ & $7.00 \pm 0.50^{\mathrm{b}}{ }_{\mathrm{BC}}$ & NA & $* 6.80 \pm 0.32^{\mathrm{bc}} \mathrm{C}$ & $* 6.50 \pm 0.24^{\mathrm{c}} \mathrm{C}$ \\
\hline & & RT & $\begin{array}{l}1 / 6 \\
1 / 3 \\
1 / 4 \\
1 / 6 \\
\end{array}$ & $\begin{array}{l}* 7.50 \pm 0.50^{\mathrm{a}}{ }_{\mathrm{A}} \\
9.50 \pm 0.50^{\mathrm{b}}{ }_{\mathrm{A}} \\
* 9.00 \pm 0.00^{\mathrm{b}} \mathrm{A} \\
* 8.50 \pm 0.50^{\mathrm{b}} \mathrm{A} \\
\end{array}$ & $\begin{array}{l}* 5.00 \pm 0.00^{\mathrm{a}}{ }_{\mathrm{B}} \\
* 8.75 \pm 0.25^{\mathrm{c}} \mathrm{A} \\
* 8.50 \pm 0.50^{\mathrm{c}} \mathrm{A} \\
* 7.75 \pm 0.25^{\mathrm{b}} \mathrm{A}\end{array}$ & $\begin{array}{c}* 3.50 \pm 0.50^{\mathrm{a}} \mathrm{C} \\
7.75 \pm 0.50^{\mathrm{c}}{ }_{\mathrm{B}} \\
* 7.70 \pm 0.25^{\mathrm{c}^{\mathrm{B}}} \\
7.00 \pm 0.25^{\mathrm{b}} \mathrm{B} \\
\end{array}$ & $\begin{array}{l}\text { NA } \\
\text { NA } \\
\text { NA } \\
\text { NA } \\
\end{array}$ & $\begin{array}{c}* 3.00 \pm 0.24^{\mathrm{a}} \mathrm{C} \\
7.50 \pm 0.30^{\mathrm{d}} \mathrm{B} \\
7.30 \pm 0.20^{\mathrm{cd}} \mathrm{C} \\
* 6.30 \pm 0.50^{\mathrm{b}} \mathrm{C} \\
\end{array}$ & $\begin{array}{c}* 2.50 \pm 0.16^{\mathrm{a}} \mathrm{D} \\
7.30 \pm 0.40^{\mathrm{e}}{ }_{\mathrm{B}} \\
7.00 \pm 0.25^{\mathrm{e}} \mathrm{C} \\
* 5.50 \pm 0.45^{\mathrm{b}} \mathrm{D} \\
7\end{array}$ \\
\hline \multirow{7}{*}{$\begin{array}{l}\bar{z} \\
\end{array}$} & & & $1 / 3$ & $* 9.95 \pm 0.05^{\mathrm{A}} \mathrm{A}$ & $* 8.90 \pm 0.10^{\circ} \mathrm{B}$ & $\frac{1.00 \pm .20 \mathrm{~B}}{* 8.90 \pm 0.01^{\mathrm{b}_{\mathrm{B}}}}$ & $7.80 \pm 0.13^{\mathrm{d}} \mathrm{C}$ & $* 7.90 \pm 0.06^{\mathrm{d}} \mathrm{C}$ & $7.30 \pm 0.12^{\mathrm{d}} \mathrm{C}$ \\
\hline & 矛 & AT & $\begin{array}{l}1 / 4 \\
1 / 6 \\
1 / 3 \\
1 / 4\end{array}$ & 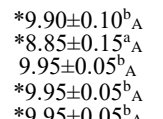 & 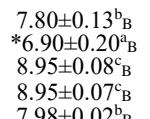 & $\begin{array}{l}* 7.80 \pm 0.11^{\mathrm{c}} \mathrm{B} \\
* 4.95 \pm 0.04^{\mathrm{a}} \mathrm{C} \\
7.95 \pm 0.03{ }^{\circ} \mathrm{C} \\
7.95 \pm 0.06{ }^{6} \mathrm{c} \\
688+0.1 \mathrm{c}^{\mathrm{b}} \mathrm{C}\end{array}$ & $\begin{array}{l}7.20 \pm 0.19^{\mathrm{d}} \mathrm{c} \\
3.75 \pm 0.21^{\mathrm{a}} \mathrm{D} \\
7.90 \pm 0.10^{\mathrm{d}} \mathrm{C} \\
6.75 \pm 0.23^{\mathrm{c}} \mathrm{D} \\
585+04^{\mathrm{b}}\end{array}$ & 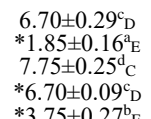 & $\begin{array}{l}* 6.40 \pm 0.21^{\mathrm{c}} \mathrm{D} \\
* 1.00 \pm 0.10^{\mathrm{a}} \mathrm{F} \\
7.50 \pm 0.15^{\mathrm{d}} \mathrm{C} \\
* 6.40 \pm 0.15^{\mathrm{CE}} \\
* 750.07 \mathrm{~b}\end{array}$ \\
\hline & \multirow{5}{*}{ 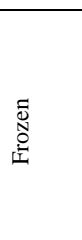 } & \multirow{4}{*}{ AT } & $\frac{1 / 6}{1 / 3}$ & $* 8.50 \pm 0.050^{\mathrm{A}}$ & $\begin{array}{l}1.98 \pm 0.02 \mathrm{~B} \\
* 8.00 \pm 0.00^{\mathrm{c}} \mathrm{AB}\end{array}$ & $\begin{array}{l}0.08 \pm 0.13^{C} \mathrm{C} \\
* 7.50 \pm 0.50^{c^{c}}\end{array}$ & $\frac{5.85 \pm 0.14^{\circ} \mathrm{D}}{\mathrm{NA}}$ & $* 7.10 \pm 0.210^{\text {cd }}{ }_{B}$ & $\frac{2.15 \pm 0.0 / \mathrm{F}}{6.90 \pm 0.40^{\mathrm{c}}{ }_{\mathrm{B}}}$ \\
\hline & & & $1 / 4$ & $* 8.00 \pm 1.00^{a^{\mathrm{ab}}}$ & $7.75 \pm 0.25^{\mathrm{bc}}{ }_{\mathrm{A}}$ & $* 7.00 \pm 0.00^{\mathrm{b}}{ }_{\mathrm{B}}$ & NA & $6.90 \pm 0.08^{c} \mathrm{C}$ & $* 6.80 \pm 0.08^{c} \mathrm{C}$ \\
\hline & & & $1 / 6$ & $* 7.50 \pm 0.50^{\mathrm{a}} \mathrm{A}$ & $* 5.50 \pm 0.50^{\mathrm{a}}{ }_{\mathrm{B}}$ & $* 3.50 \pm 0.50^{\mathrm{a}} \mathrm{C}$ & NA & $* 3.10 \pm 0.20^{\mathrm{a}} \mathrm{C}$ & $* 2.40 \pm 0.42^{\mathrm{a}} \mathrm{D}$ \\
\hline & & & $1 / 3$ & $9.50 \pm 0.50^{\mathrm{cd}_{\mathrm{A}}}$ & $8.75 \pm 0.25^{\mathrm{d}}$ & $7.80 \pm 0.13^{\mathrm{c}} \mathrm{C}$ & $\mathrm{NA}$ & $7.40 \pm 0.10^{\mathrm{e}} \mathrm{D}$ & $7.20 \pm 0.24^{\mathrm{c}} \mathrm{D}$ \\
\hline & & RT & $1 / 6$ & $* 9.00 \pm 0.20^{\mathrm{c}} \mathrm{A}$ & $7.50 \pm 0.50^{\mathrm{b}}{ }_{\mathrm{B}}$ & $6.75 \pm 0.25^{\mathrm{b}} \mathrm{C}$ & NA & $* 6.20 \pm 0.20^{\mathrm{b}}$ & $* 5.75 \pm 0.15^{\mathrm{b}} \mathrm{E}$ \\
\hline \multirow{11}{*}{ 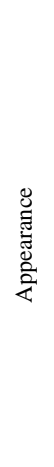 } & \multirow{6}{*}{ 矛 } & \multirow{4}{*}{ AT } & $1 / 3$ & $9.90 \pm 0.10^{\mathrm{b}} \mathrm{A}$ & $* 9.90 \pm 0.10^{\mathrm{d}}{ }_{\mathrm{A}}$ & $* 9.00 \pm 0.00^{\mathrm{d}}{ }_{\mathrm{B}}$ & $7.90 \pm 0.03^{\mathrm{d}} \mathrm{C}$ & $7.30 \pm 0.30^{\mathrm{d}} \mathrm{D}$ & $6.90 \pm 0.20^{\mathrm{e}} \mathrm{D}$ \\
\hline & & & $1 / 4$ & $* 9.80 \pm 0.20^{\mathrm{b}} \mathrm{A}$ & $* 8.80 \pm 0.13^{c_{B}}$ & $* 8.30 \pm 0.34^{c} \mathrm{C}$ & $7.55 \pm 0.04^{\mathrm{d}} \mathrm{D}$ & $* 6.20 \pm 0.20^{\mathrm{c}} \mathrm{E}$ & $* 5.90 \pm 0.30^{c} \mathrm{E}$ \\
\hline & & & $1 / 6$ & $8.70 \pm 0.30^{\mathrm{a}}{ }_{\mathrm{A}}$ & $6.70 \pm 0.23^{\mathrm{a}}{ }_{\mathrm{B}}$ & $* 4.90 \pm 0.01^{\mathrm{a}} \mathrm{C}$ & $3.85 \pm 0.15^{\mathrm{a}} \mathrm{D}$ & $* 2.90 \pm 0.08^{\mathrm{a}} \mathrm{E}$ & $* 1.40 \pm 0.32^{\mathrm{a}} \mathrm{F}$ \\
\hline & & & $1 / 3$ & $9.95 \pm 0.05^{\mathrm{b}} \mathrm{A}$ & $* 9.90 \pm 0.10^{\mathrm{d}} \mathrm{A}$ & $8.35 \pm 0.35^{\mathrm{c}} \mathrm{B}$ & $7.95 \pm 0.04^{\mathrm{d}} \mathrm{C}$ & $7.90 \pm 0.08^{\mathrm{e}} \mathrm{C}$ & $7.70 \pm 0.18^{\mathrm{f}} \mathrm{C}$ \\
\hline & & \multirow{2}{*}{ RT } & $1 / 4$ & $* 9.95 \pm 0.05^{\mathrm{b}}{ }_{\mathrm{A}}$ & $* 9.85 \pm 0.15^{\mathrm{d}}{ }_{\mathrm{A}}$ & $8.20 \pm 0.20^{c_{B}}$ & $6.90 \pm 0.01^{\mathrm{c}} \mathrm{C}$ & $* 6.55 \pm 0.11^{\mathrm{c}} \mathrm{D}$ & $* 6.25 \pm 0.16_{\mathrm{E}}^{\mathrm{d}}$ \\
\hline & & & $\frac{1 / 6}{1 / 3}$ & $\frac{* 9.90 \pm 0.10^{\mathrm{b}} \mathrm{A}}{9.50 \pm 0.50^{\mathrm{b}}{ }_{\mathrm{A}}}$ & $\frac{* 7.80 \pm 0.20^{\mathrm{b}}{ }_{\mathrm{B}}}{* 8.25 \pm 0.25^{\mathrm{cod}_{\mathrm{B}}}}$ & $\frac{7.05 \pm 0.05^{\mathrm{b}} \mathrm{c}}{* 7.60 \pm 0.25^{\mathrm{d}} \mathrm{c}}$ & $\frac{5.85 \pm 0.11^{\mathrm{b}} \mathrm{D}}{\mathrm{NA}}$ & $\frac{* 3.75 \pm 0.28^{\mathrm{b}} \mathrm{E}}{7.00 \pm 0.30^{\mathrm{d}}}$ & $\frac{* 3.00 \pm 0.18^{\mathrm{b}}{ }_{\mathrm{E}}}{6.80 \pm 0.20^{\mathrm{c}} \mathrm{C}}$ \\
\hline & \multirow{5}{*}{ 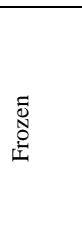 } & \multirow{3}{*}{ AT } & $1 / 4$ & $* 8.75 \pm 0.25^{\mathrm{a}}{ }_{\mathrm{A}}$ & $* 7.75 \pm 0.25^{c_{B}}$ & $* 6.75 \pm 0.50^{\mathrm{b}} \mathrm{C}$ & NA & $* 6.70 \pm 0.30^{c}{ }_{C}$ & $* 6.70 \pm 0.10^{c^{c}}$ \\
\hline & & & $1 / 6$ & $8.50 \pm 0.50^{\mathrm{a}} \mathrm{A}$ & $6.50 \pm 0.50^{\mathrm{a}} \mathrm{B}$ & $* 3.25 \pm 0.50^{\mathrm{a} C}$ & NA & $* 3.00 \pm 0.10^{\mathrm{a} C}$ & $* 2.20 \pm 0.32^{\mathrm{a}} \mathrm{D}$ \\
\hline & & & $1 / 3$ & $9.50 \pm 0.50^{\mathrm{b}}{ }_{\mathrm{A}}$ & $* 8.75 \pm 0.25^{\mathrm{d}} \mathrm{B}$ & $8.30 \pm 0.25^{\mathrm{e}} \mathrm{C}$ & $\mathrm{NA}$ & $7.90 \pm 0.15^{\mathrm{e}} \mathrm{D}$ & $7.50 \pm 0.15^{\mathrm{d}} \mathrm{E}$ \\
\hline & & \multirow{2}{*}{ RT } & $1 / 4$ & $* 9.00 \pm 0.50^{\mathrm{ab}_{\mathrm{A}}}$ & $* 8.00 \pm 0.00^{c_{B}}$ & $7.25 \pm 0.50^{\mathrm{c}} \mathrm{C}$ & NA & $* 7.20 \pm 0.12^{\mathrm{d}} \mathrm{C}$ & $* 7.00 \pm 0.10^{c_{C}}$ \\
\hline & & & $1 / 6$ & $* 8.75 \pm 0.50^{\mathrm{a}} \mathrm{A}$ & $* 7.30 \pm 0.38^{\mathrm{b}}{ }_{\mathrm{B}}$ & $7.00 \pm 0.25^{\mathrm{bc}} \mathrm{B}_{\mathrm{B}}$ & NA & $* 6.30 \pm 0.16^{\mathrm{b}} \mathrm{C}$ & $* 5.40 \pm 0.20^{\mathrm{b}} \mathrm{D}$ \\
\hline
\end{tabular}

A: Analysis, RW: Raw Material Type, ST: Storage Temperature, SFR: The ratio of salt:fish (w:w), AT: Ambient Temperature, RT: Refrigerated Temperature, NA: Not Analysed, \pm SD: $n: 8$, The values below 4.0 is unacceptable.
The different superscript lowercase letters (a,b,c.) represent statistical differences amongst different salting subroups under each raw material group at the same storage time ( $p<0.05)$. The different subscript uppercase letters (A,B,C...) The different superscript lowercase letters $(a, b, c .$.$) represent statistical differences amongst different salting subgroups under each raw material group at the same storage time ( <<0.05)$. The different subscript uppercase letters $(A, B, C . .$.
represents statistical differences during storage period of the same group $(p<0.05)$.' ' on each data represents that there is statistical difference between the data obtained for fresh and frozen raw material groups at the same storage time represents statistical differenc 


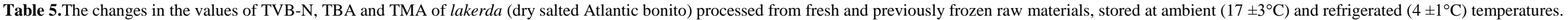

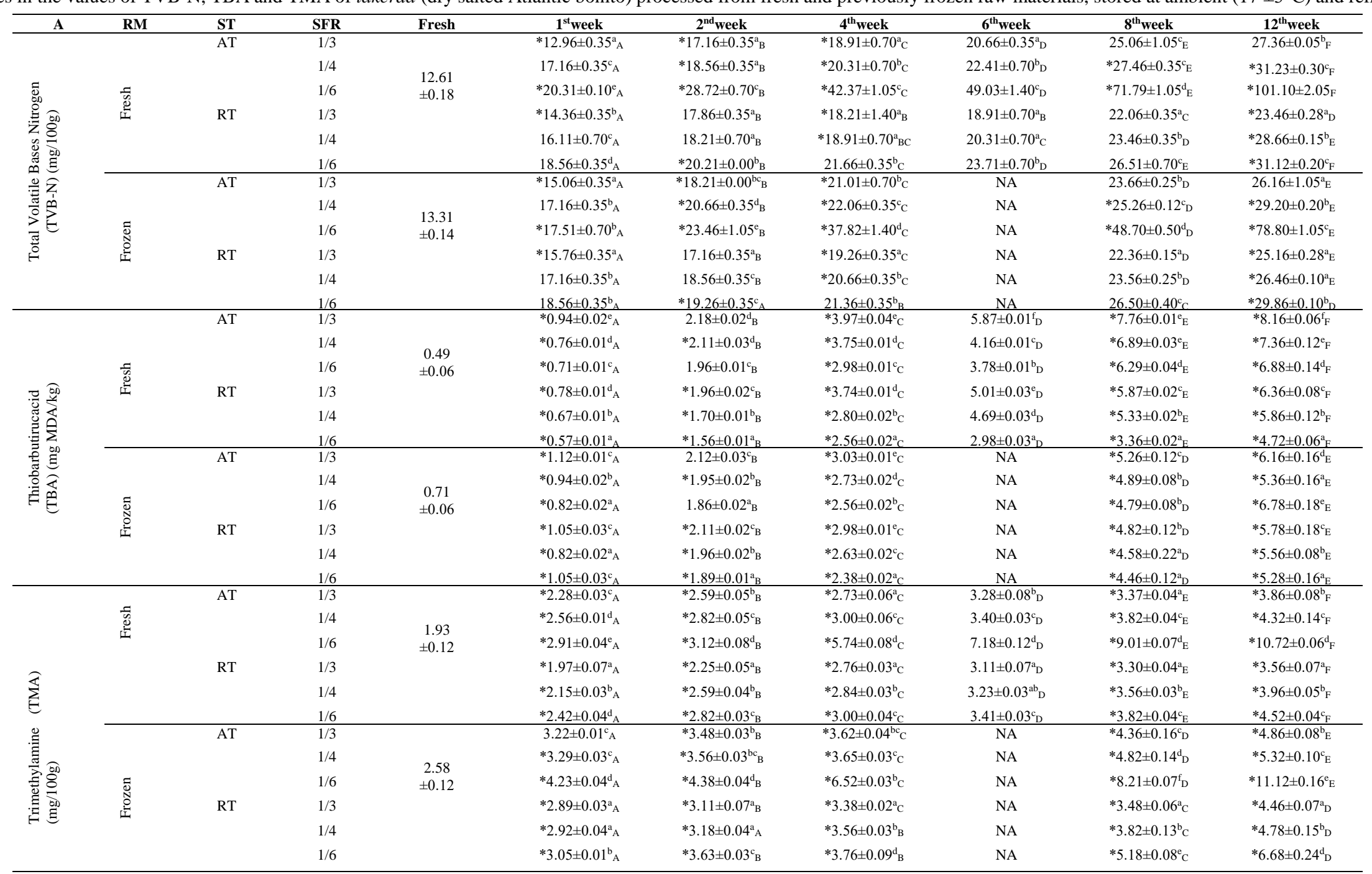

A: Analysis, RW: Raw Material Type, ST: Storage Temperature, SFR: The ratio of salt:fish(w:w), AT: Ambient Temperature, RT: Refrigerated Temperature, NA: Not Analysed, \pm SD: $n: 3$, The different superscript lowercase letters $(a, b, c .$.$) represent statistical differences amongst different salting subgroups under each raw material group at the same storage time ( p<0.05)$. The different subscript uppercase letters $(A, B, C . .$. represents statistical differences during storage period of the same group $(p<0.05)$. '*' on each data represents that there is statistical difference between the data obtained for fresh and frozen raw material groups at the same storage time and the ration of salt:fish. 
Table 6. The changes in the biogenic amine contents of lakerda (dry salted Atlantic bonito) processed from fresh raw material stored at ambient $\left(17 \pm 3^{\circ} \mathrm{C}\right)$ and refrigerated $\left(4 \pm 1^{\circ} \mathrm{C}\right)$ temperatures.

\begin{tabular}{|c|c|c|c|c|c|c|c|c|c|c|}
\hline \multirow{2}{*}{$\begin{array}{l}\text { Storage } \\
\text { Time }\end{array}$} & \multirow{2}{*}{$\begin{array}{l}\text { Storage } \\
\text { Temp. }\end{array}$} & $\begin{array}{c}\text { SFR } \\
\text { Groups }\end{array}$ & $\begin{array}{c}\text { Tryptamine } \\
(\mathbf{p p m})\end{array}$ & $\begin{array}{c}\text { Phenethylamine } \\
\text { (ppm) }\end{array}$ & $\begin{array}{c}\text { Putrescine } \\
(\mathbf{p p m})\end{array}$ & $\begin{array}{c}\begin{array}{c}\text { Cadaverine } \\
(\mathbf{p p m})\end{array} \\
\end{array}$ & $\begin{array}{c}\text { Histamine } \\
(\mathbf{p p m})\end{array}$ & Tyramine (ppm) & Spermidine (ppm) & $\begin{array}{c}\text { Spermine } \\
(\mathbf{p p m})\end{array}$ \\
\hline & & Fresh & $5.62 \pm 0.05^{\mathrm{c}}$ & $14.67 \pm 0.29^{\mathrm{a}}$ & $3.89 \pm 0.03^{\mathrm{g}}$ & $1.51 \pm 0.17^{\mathrm{d}}$ & $<0.86^{*}$ & $22.40 \pm 0.16^{\mathrm{c}}$ & $162.59 \pm 0.40^{\mathrm{c}}$ & $1.44 \pm 0.03^{\mathrm{a}}$ \\
\hline \multirow{6}{*}{$\begin{array}{c}1^{\text {st }} \\
\text { week }\end{array}$} & \multirow{3}{*}{ Ambient } & $1 / 3$ & $5.75 \pm 0.14^{\mathrm{c}}{ }_{\mathrm{B}}$ & $* 30.42 \pm 0.60^{c}{ }_{D}$ & $* 3.21 \pm 0.05^{\mathrm{e}} \mathrm{D}$ & $* 1.11 \pm 0.06^{\mathrm{b}} \mathrm{C}$ & $* 3.23 \pm 0.05^{\mathrm{b}}{ }_{\mathrm{B}}$ & $12.81 \pm 0.17^{\mathrm{b}}$ & $* 114.46 \pm 0.66^{\mathrm{b}}{ }_{\mathrm{C}}$ & $* 8.58 \pm 0.10^{\mathrm{d}} \mathrm{D}$ \\
\hline & & $1 / 4$ & $* 6.50 \pm 0.08^{\mathrm{d}}{ }_{\mathrm{B}}$ & $* 22.91 \pm 0.08^{\mathrm{b}} \mathrm{C}$ & $* 3.42 \pm 0.12_{\mathrm{D}}^{\mathrm{f}}$ & $* 2.74 \pm 0.05^{\mathrm{f}} \mathrm{C}$ & $* 6.17 \pm 0.16_{\mathrm{A}}^{\mathrm{c}}$ & $11.37 \pm 0.01^{\mathrm{a}}{ }_{\mathrm{D}}$ & $* 109.45 \pm 0.68^{\mathrm{b}}{ }_{\mathrm{D}}$ & $4.48 \pm 0.08^{\mathrm{c}}{ }_{\mathrm{C}}$ \\
\hline & & $1 / 6$ & $* 6.43 \pm 0.06^{\mathrm{d}}{ }_{\mathrm{B}}$ & $* 29.99 \pm 0.14_{\mathrm{D}}^{\mathrm{c}}$ & $* 3.00 \pm 0.12^{\mathrm{d}}$ & $* 1.50 \pm 0.06^{\mathrm{d}}{ }_{\mathrm{A}}$ & $* 9.34 \pm 0.22^{\mathrm{d}}{ }_{\mathrm{A}}$ & $12.92 \pm 0.13^{\mathrm{b}}$ & $* 114.62 \pm 0.63^{b}{ }_{D}$ & $* 3.49 \pm 0.07^{\mathrm{b}} \mathrm{B}$ \\
\hline & \multirow{3}{*}{$\begin{array}{l}\text { Refriger- } \\
\text { ator }\end{array}$} & $1 / 3$ & $* 4.62 \pm 0.16_{\mathrm{A}}^{\mathrm{a}}$ & $* 36.39 \pm 0.18^{\mathrm{f}}$ & $* 2.09 \pm 0.03^{\mathrm{b}}$ & $* 0.39 \pm 0.02^{\mathrm{a}}{ }_{\mathrm{A}}$ & $* 0.95 \pm 0.03^{\mathrm{a}}{ }_{\mathrm{A}}$ & $11.12 \pm 0.20^{\mathrm{a}}$ & $* 110.02 \pm 0.54_{D}^{b}$ & $* 4.40 \pm 0.25^{\mathrm{c}} \mathrm{D}$ \\
\hline & & $1 / 4$ & $5.15 \pm 0.11^{\mathrm{b}}{ }_{\mathrm{A}}$ & $* 32.13 \pm 0.52^{\mathrm{d}}{ }_{\mathrm{D}}$ & $* 1.93 \pm 0.06^{\mathrm{a}} \mathrm{C}$ & $* 1.89 \pm 0.06^{\mathrm{e}} \mathrm{C}$ & $* 0.94 \pm 0.01^{\mathrm{a}}{ }_{\mathrm{A}}$ & $* 11.40 \pm 0.17^{\mathrm{a}} \mathrm{C}$ & $103.82 \pm 0.42^{\mathrm{a}}{ }_{\mathrm{D}}$ & $4.51 \pm 0.05^{\mathrm{c}}{ }_{\mathrm{D}}$ \\
\hline & & $1 / 6$ & $* 4.73 \pm 0.06^{\mathrm{a}}{ }_{\mathrm{B}}$ & $* 34.93 \pm 0.20^{\mathrm{e}} \mathrm{D}$ & $* 2.72 \pm 0.06^{\mathrm{c}} \mathrm{D}$ & $* 1.25 \pm 0.04^{\mathrm{c}}{ }_{\mathrm{B}}$ & $<0.86^{*}$ & $* 11.61 \pm 0.09^{\mathrm{a}} \mathrm{C}$ & $* 110.13 \pm 0.44^{\mathrm{b}}$ & $* 4.75 \pm 0.14^{\mathrm{c}} \mathrm{D}$ \\
\hline \multirow{6}{*}{$\begin{array}{c}4^{\text {th }} \\
\text { week }\end{array}$} & \multirow{3}{*}{ Ambient } & $1 / 3$ & $* 7.41 \pm 0.07^{b}$ & $* 21.58 \pm 0.09^{\mathrm{c}}{ }_{\mathrm{B}}$ & $* 2.38 \pm 0.08^{\mathrm{c}}$ & $* 0.82 \pm 0.07^{b}$ & $* 6.44 \pm 0.13^{\mathrm{d}} \mathrm{C}$ & $* 10.57 \pm 0.32^{\mathrm{c}}{ }_{\mathrm{B}}$ & $* 100.21 \pm 1.16^{\mathrm{d}}{ }_{\mathrm{B}}$ & $* 3.19 \pm 0.06^{\mathrm{a}}{ }_{\mathrm{A}}$ \\
\hline & & $1 / 4$ & $* 7.34 \pm 0.23^{b}{ }_{C}$ & $* 24.03 \pm 0.02^{\mathrm{d}}{ }_{\mathrm{D}}$ & $* 2.41 \pm 0.05^{\mathrm{d}} \mathrm{C}$ & $0.40 \pm 0.02^{\mathrm{a}}{ }_{\mathrm{A}}$ & $* 7.35 \pm 0.23^{\mathrm{e}}$ & $* 10.80 \pm 0.06^{\mathrm{c}} \mathrm{C}$ & $* 97.75 \pm 0.07^{\mathrm{c}} \mathrm{C}$ & $* 3.52 \pm 0.04^{\mathrm{b}}{ }_{\mathrm{A}}$ \\
\hline & & $1 / 6$ & $* 9.53 \pm 0.43^{\mathrm{c}}{ }_{\mathrm{D}}$ & $* 24.36 \pm 0.32^{\mathrm{d}} \mathrm{C}$ & $* 2.85 \pm 0.13^{\mathrm{e}}$ & $* 2.54 \pm 0.11^{\mathrm{d}}{ }_{\mathrm{C}}$ & $* 12.01 \pm 0.12^{\mathrm{f}} \mathrm{B}$ & $* 8.90 \pm 0.07^{\mathrm{a}} \mathrm{C}$ & $* 80.25 \pm 0.33^{\mathrm{a}} \mathrm{C}$ & $* 3.50 \pm 0.06^{\mathrm{b}}{ }_{\mathrm{B}}$ \\
\hline & \multirow{3}{*}{ Refrigerator } & $1 / 3$ & $5.53 \pm 0.12^{\mathrm{a}}{ }_{\mathrm{B}}$ & $* 15.87 \pm 0.09^{\mathrm{b}} \mathrm{C}$ & $1.70 \pm 0.05^{\mathrm{b}}{ }_{\mathrm{B}}$ & $1.59 \pm 0.04^{\mathrm{c}}{ }_{\mathrm{C}}$ & $* 1.21 \pm 0.04^{\mathrm{a}}{ }_{\mathrm{B}}$ & $* 9.58 \pm 0.08^{\mathrm{b}}{ }_{\mathrm{A}}$ & $88.10 \pm 0.15^{\mathrm{b}}{ }_{\mathrm{B}}$ & $* 3.07 \pm 0.06^{\mathrm{a}}{ }_{\mathrm{A}}$ \\
\hline & & $1 / 4$ & $5.53 \pm 0.13^{\mathrm{a}}{ }_{\mathrm{B}}$ & $* 15.71 \pm 0.07^{\mathrm{b}}{ }_{\mathrm{B}}$ & $* 1.59 \pm 0.04^{\mathrm{a}}{ }_{\mathrm{B}}$ & $* 0.40 \pm 0.02^{\mathrm{a}}{ }_{\mathrm{A}}$ & $1.50 \pm 0.05^{\mathrm{b}}{ }_{\mathrm{B}}$ & $* 8.74 \pm 0.16^{a}{ }_{B}$ & $* 79.70 \pm 0.14^{\mathrm{a}}{ }_{\mathrm{B}}$ & $* 3.48 \pm 0.09^{\mathrm{b}}{ }_{\mathrm{A}}$ \\
\hline & & $1 / 6$ & $5.41 \pm 0.10^{\mathrm{a}} \mathrm{C}$ & ${ }^{*} 14.07 \pm 0.03^{\mathrm{a}} \mathrm{C}$ & $* 2.28 \pm 0.08^{\mathrm{c}} \mathrm{C}$ & $0.36 \pm 0.01^{\mathrm{a}}{ }_{\mathrm{A}}$ & $* 1.72 \pm 0.07^{\mathrm{c}}{ }_{\mathrm{A}}$ & $* 12.22 \pm 0.21^{\mathrm{d}}{ }_{\mathrm{D}}$ & $* 105.62 \pm 0.51^{\mathrm{e}}{ }_{\mathrm{C}}$ & $* 3.58 \pm 0.07^{\mathrm{b}}$ \\
\hline \multirow{6}{*}{$\begin{array}{c}8^{\text {th }} \\
\text { week }\end{array}$} & \multirow{3}{*}{ Ambient } & $1 / 3$ & $* 6.75 \pm 0.11^{\mathrm{c}} \mathrm{C}$ & $* 28.02 \pm 0.10_{\mathrm{C}}^{\mathrm{f}}$ & $* 2.78 \pm 0.07^{\mathrm{d}} \mathrm{C}$ & $* 0.42 \pm 0.03^{\mathrm{a}}{ }_{\mathrm{A}}$ & $* 6.98 \pm 0.07^{\mathrm{d}}{ }_{\mathrm{D}}$ & $* 11.65 \pm 0.24^{\mathrm{c}} \mathrm{C}$ & $* 102.15 \pm 0.20^{\mathrm{d}}{ }_{\mathrm{B}}$ & $3.66 \pm 0.13^{\mathrm{a}}{ }_{\mathrm{B}}$ \\
\hline & & $1 / 4$ & $* 7.15 \pm 0.11^{\mathrm{d}} \mathrm{C}$ & $* 17.23 \pm 0.05^{\mathrm{d}}{ }_{\mathrm{B}}$ & $* 1.84 \pm 0.06^{\mathrm{b}}{ }_{\mathrm{B}}$ & $* 0.41 \pm 0.02^{\mathrm{a}}{ }_{\mathrm{A}}$ & $* 8.20 \pm 0.05^{\mathrm{e}}{ }_{\mathrm{D}}$ & $* 9.93 \pm 0.19^{\mathrm{b}}{ }_{\mathrm{B}}$ & $* 86.07 \pm 0.29^{\mathrm{b}}{ }_{\mathrm{B}}$ & $* 3.43 \pm 0.16^{\mathrm{a}}{ }_{\mathrm{A}}$ \\
\hline & & $1 / 6$ & $* 7.74 \pm 0.15^{\mathrm{e}}{ }_{C}$ & $* 19.75 \pm 0.48^{\mathrm{e}}{ }_{\mathrm{B}}$ & $* 2.82 \pm 0.07^{\mathrm{d}}$ & $* 2.31 \pm 0.06^{\mathrm{c}}{ }_{\mathrm{B}}$ & $* 17.18 \pm 0.05_{\mathrm{D}}^{\mathrm{f}}$ & $* 6.43 \pm 0.24^{\mathrm{a}}{ }_{\mathrm{B}}$ & $* 61.77 \pm 0.26^{\mathrm{a}}{ }_{\mathrm{B}}$ & $* 3.53 \pm 0.03^{\mathrm{a}}{ }_{\mathrm{B}}$ \\
\hline & \multirow{3}{*}{ Refrigerator } & $1 / 3$ & $* 5.62 \pm 0.06^{\mathrm{a}}{ }_{\mathrm{B}}$ & $* 4.97 \pm 0.05^{\mathrm{a}}{ }_{\mathrm{A}}$ & $* 1.97 \pm 0.02^{\mathrm{c}} \mathrm{C}$ & $* 0.45 \pm 0.05^{\mathrm{a}}{ }_{\mathrm{A}}$ & $* 1.44 \pm 0.01^{\mathrm{a}} \mathrm{C}$ & $11.46 \pm 0.19^{c}{ }_{B}$ & $* 95.97 \pm 0.26^{\mathrm{c}}{ }_{\mathrm{C}}$ & $3.38 \pm 0.07^{\mathrm{a}}{ }_{\mathrm{B}}$ \\
\hline & & $1 / 4$ & $* 5.90 \pm 0.09^{\mathrm{b}} \mathrm{C}$ & $* 12.48 \pm 0.08^{\mathrm{c}}{ }_{\mathrm{A}}$ & $* 1.88 \pm 0.05^{\mathrm{b}}{ }_{\mathrm{C}}$ & $* 1.92 \pm 0.03^{\mathrm{b}} \mathrm{C}$ & $* 2.25 \pm 0.10^{\mathrm{b}} \mathrm{C}$ & $* 11.35 \pm 0.21^{\mathrm{c}} \mathrm{C}$ & $* 94.95 \pm 0.31^{\mathrm{c}} \mathrm{C}$ & $* 3.64 \pm 0.05^{\mathrm{a}}{ }_{\mathrm{B}}$ \\
\hline & & $1 / 6$ & $* 5.50 \pm 0.06^{\mathrm{a}}{ }_{\mathrm{C}}$ & $* 5.93 \pm 0.06^{\mathrm{b}}{ }_{\mathrm{A}}$ & $* 1.65 \pm 0.01^{\mathrm{a}}{ }_{\mathrm{B}}$ & $* 0.37 \pm 0.01^{\mathrm{a}}{ }_{\mathrm{A}}$ & $* 2.62 \pm 0.06^{\mathrm{c}} \mathrm{B}$ & $* 10.84 \pm 0.05^{\mathrm{c}} \mathrm{B}$ & $* 87.90 \pm 0.08^{\mathrm{b}}$ & $* 3.25 \pm 0.04^{\mathrm{a}}{ }_{\mathrm{A}}$ \\
\hline \multirow{6}{*}{$\begin{array}{l}12^{\text {th }} \\
\text { week }\end{array}$} & \multirow{3}{*}{ Ambient } & $1 / 3$ & $4.75 \pm 0.03^{\mathrm{b}}{ }_{\mathrm{A}}$ & $* 0.85 \pm 0.04_{\mathrm{A}}^{\mathrm{b}}$ & $0.53 \pm 0.02^{\mathrm{a}} \mathrm{A}$ & $0.91 \pm 0.02^{\mathrm{b}}{ }_{\mathrm{B}}$ & $3.03 \pm 0.02^{\mathrm{c}}{ }_{\mathrm{A}}$ & $5.18 \pm 0.08^{\mathrm{c}}{ }_{\mathrm{A}}$ & $* 66.56 \pm 0.23^{\mathrm{e}}{ }_{\mathrm{A}}$ & $* 4.91 \pm 0.02^{\mathrm{d}} \mathrm{C}$ \\
\hline & & $1 / 4$ & $* 4.82 \pm 0.08^{\mathrm{b}}$ & $* 0.72 \pm 0.01^{\mathrm{a}}{ }_{\mathrm{A}}$ & $* 0.52 \pm 0.01^{\mathrm{a}}{ }_{\mathrm{A}}$ & $* 0.73 \pm 0.02^{\mathrm{a}}{ }_{\mathrm{B}}$ & $* 7.88 \pm 0.03^{\mathrm{e}} \mathrm{C}$ & $* 4.18 \pm 0.06^{\mathrm{b}}$ & $* 56.38 \pm 0.25^{\mathrm{b}}{ }_{\mathrm{A}}$ & $* 4.28 \pm 0.02^{\mathrm{c}}{ }_{\mathrm{B}}$ \\
\hline & & $1 / 6$ & $* 4.75 \pm 0.06^{\mathrm{b}}{ }_{\mathrm{A}}$ & $* 2.90 \pm 0.09^{\mathrm{c}} \mathrm{A}$ & $* 1.22 \pm 0.01^{\mathrm{c}}$ & $4.65 \pm 0.05^{\mathrm{e}} \mathrm{D}$ & $* 16.95 \pm 0.02^{\mathrm{f}} \mathrm{C}$ & $* 2.90 \pm 0.09^{\mathrm{a}}{ }_{\mathrm{A}}$ & $* 14.42 \pm 0.13^{\mathrm{a}}{ }_{\mathrm{A}}$ & $* 2.23 \pm 0.02^{\mathrm{a}} \mathrm{A}$ \\
\hline & \multirow{3}{*}{ Refrigerator } & $1 / 3$ & $4.56 \pm 0.02^{\mathrm{a}}{ }_{\mathrm{A}}$ & $* 13.16 \pm 0.02^{\mathrm{e}}{ }_{\mathrm{B}}$ & $0.72 \pm 0.01_{\mathrm{A}}^{\mathrm{b}}$ & $* 1.08 \pm 0.01^{\mathrm{c}}{ }_{\mathrm{B}}$ & $1.67 \pm 0.03^{\mathrm{a}} \mathrm{C}$ & $* 11.68 \pm 0.10^{\mathrm{d}}{ }_{\mathrm{B}}$ & $* 59.93 \pm 0.20^{\mathrm{c}}{ }_{\mathrm{A}}$ & $* 3.93 \pm 0.03^{\mathrm{b}} \mathrm{C}$ \\
\hline & & $1 / 4$ & $4.63 \pm 0.05_{\mathrm{A}}^{\mathrm{a}}$ & $* 16.16 \pm 0.08_{C}^{\mathrm{f}}$ & $* 0.59 \pm 0.01^{\mathrm{a}}{ }_{\mathrm{A}}$ & $* 0.71 \pm 0.01^{\mathrm{a}}{ }_{\mathrm{B}}$ & $2.88 \pm 0.08^{\mathrm{b}} \mathrm{D}$ & $* 5.25 \pm 0.04_{\mathrm{A}}^{\mathrm{c}}$ & $* 63.75 \pm 0.08^{\mathrm{d}}{ }_{\mathrm{A}}$ & $* 4.28 \pm 0.01^{\mathrm{c}} \mathrm{C}$ \\
\hline & & $1 / 6$ & $* 4.58 \pm 0.02^{\mathrm{a}}{ }_{\mathrm{A}}$ & $* 10.15 \pm 0.09^{\mathrm{d}}{ }_{\mathrm{B}}$ & $* 0.48 \pm 0.01^{\mathrm{a}}{ }_{\mathrm{A}}$ & $* 1.26 \pm 0.01^{\mathrm{d}_{\mathrm{B}}}$ & $* 4.38 \pm 0.09^{\mathrm{d}}{ }_{\mathrm{C}}$ & $* 5.18 \pm 0.06^{\mathrm{c}}{ }_{\mathrm{A}}$ & $* 71.30 \pm 0.08_{\mathrm{A}}^{\mathrm{f}}$ & $* 4.20 \pm 0.05^{\mathrm{c}} \mathrm{C}$ \\
\hline
\end{tabular}

$\pm S D, n=3$, *: SFR: The ratio of salt:fish (w:w), The levels were under detection limit. The different lowercase letters (a,b,c..) represent statistical differences amongst groups at the same storage time $(p<0.05)$. The different uppercase letters $(A, B, C \ldots . .$.$) represents statistical differences during storage period of the same group (p<0.05)$. '*' on each data represents that there is statistical difference between the data obtained for frozen raw material group relating to the same storage time and the same salt concentration ratio. 
Table 7. The changes in the biogenic amine contents of lakerda (dry salted Atlantic bonito) processed from frozen raw material stored at ambient $\left(17 \pm 3^{\circ} \mathrm{C}\right)$ and refrigerated $\left(4 \pm 1^{\circ} \mathrm{C}\right)$ temperatures.

\begin{tabular}{|c|c|c|c|c|c|c|c|c|c|c|}
\hline Storage & Storage & $\begin{array}{c}\text { SFR } \\
\text { Groups }\end{array}$ & $\begin{array}{c}\text { Tryptamine } \\
(\mathbf{p p m})\end{array}$ & $\begin{array}{c}\text { Phenethylamine } \\
\text { (ppm) }\end{array}$ & $\begin{array}{c}\text { Putrescine } \\
\text { (ppm) }\end{array}$ & $\begin{array}{c}\text { Cadaverine } \\
(\mathbf{p p m})\end{array}$ & $\begin{array}{c}\text { Histamine } \\
(\mathbf{p p m})\end{array}$ & $\begin{array}{c}\text { Tyramine } \\
(\mathbf{p p m})\end{array}$ & $\begin{array}{c}\text { Spermidine } \\
(\mathbf{p p m})\end{array}$ & $\begin{array}{c}\text { Spermine } \\
(\mathbf{p p m})\end{array}$ \\
\hline & & Fresh & $4.52 \pm 0.04^{\mathrm{a}}$ & $30.77 \pm 0.35^{\mathrm{f}}$ & $2.07 \pm 0.06^{\mathrm{c}}$ & $1.76 \pm 0.02^{\mathrm{b}}$ & $<0.86^{*}$ & $5.92 \pm 0.06^{\mathrm{a}}$ & $96.67 \pm 0.21^{\mathrm{c}}$ & $4.69 \pm 0.09^{\mathrm{b}}$ \\
\hline \multirow{6}{*}{$\begin{array}{c}1^{\text {st }} \\
\text { week }\end{array}$} & \multirow{3}{*}{ Ambient } & $1 / 3$ & $5.98 \pm 0.14^{\mathrm{e}} \mathrm{B}$ & $* 13.54 \pm 0.15^{\mathrm{c}} \mathrm{C}$ & $* 2.11 \pm 0.10^{\mathrm{c}} \mathrm{D}$ & $* 0.40 \pm 0.02^{\mathrm{a}} \mathrm{A}$ & $* 1.30 \pm 0.09^{\mathrm{b}} \mathrm{A}$ & $13.75 \pm 0.13^{\mathrm{d}_{\mathrm{D}}}$ & $* 98.59 \pm 0.44^{\mathrm{c}} \mathrm{D}$ & $* 5.45 \pm 0.23^{\mathrm{d}} \mathrm{D}$ \\
\hline & & $1 / 4$ & $* 5.37 \pm 0.08^{\mathrm{c}} \mathrm{C}$ & $* 13.94 \pm 0.05^{\mathrm{c}} \mathrm{C}$ & $* 1.98 \pm 0.07^{\mathrm{c}} \mathrm{C}$ & $* 0.76 \pm 0.04^{\mathrm{b}}{ }_{\mathrm{B}}$ & $* 1.52 \pm 0.02^{\mathrm{c}} \mathrm{A}$ & $11.86 \pm 0.19^{\mathrm{b}} \mathrm{C}$ & $* 79.68 \pm 0.11^{\mathrm{a}} \mathrm{C}$ & $4.45 \pm 0.20^{\mathrm{a}} \mathrm{B}$ \\
\hline & & $1 / 6$ & $* 5.19 \pm 0.06^{\mathrm{b}}{ }_{\mathrm{B}}$ & $* 9.79 \pm 0.09^{\mathrm{b}}{ }_{\mathrm{B}}$ & $* 2.50 \pm 0.09^{\mathrm{d}} \mathrm{D}$ & $* 2.26 \pm 0.06^{c} \mathrm{C}$ & $* 7.09 \pm 0.04 \mathrm{~d}_{\mathrm{A}}$ & $12.93 \pm 0.12^{\mathrm{c}} \mathrm{D}$ & $* 99.40 \pm 0.28^{\mathrm{c}}{ }_{\mathrm{D}}$ & $* 4.42 \pm 0.15^{\mathrm{a}} \mathrm{A}$ \\
\hline & \multirow{3}{*}{ Refrigerator } & $1 / 3$ & $* 5.52 \pm 0.04^{\mathrm{d}} \mathrm{C}$ & $* 2.28 \pm 0.04^{\mathrm{a}} \mathrm{A}$ & $* 1.59 \pm 0.04^{\mathrm{a}}{ }_{\mathrm{B}}$ & $* 1.53 \pm 0.06^{\mathrm{b}} \mathrm{A}$ & $<0.86^{*}$ & $11.70 \pm 0.19^{\mathrm{b}} \mathrm{D}$ & $* 91.93 \pm 0.13^{\mathrm{b}} \mathrm{C}$ & $* 4.69 \pm 0.09^{\mathrm{b}} \mathrm{D}$ \\
\hline & & $1 / 4$ & $5.30 \pm 0.17^{\mathrm{c}} \mathrm{C}$ & $* 25.93 \pm 0.06^{\mathrm{e}} \mathrm{D}$ & $1.83 \pm 0.06^{\mathrm{b}} \mathrm{C}$ & $* 2.69 \pm 0.09^{\mathrm{d}} \mathrm{C}$ & $* 1.17 \pm 0.08^{\mathrm{b}} \mathrm{A}$ & $* 13.50 \pm 0.40^{\mathrm{d}} \mathrm{D}$ & $104.76 \pm 0.13^{\mathrm{d}} \mathrm{D}$ & $4.51 \pm 0.05^{\mathrm{a}} \mathrm{B}$ \\
\hline & & $1 / 6$ & $* 5.28 \pm 0.08^{\mathrm{bc}}{ }_{\mathrm{C}}$ & $* 17.73 \pm 0.17^{\mathrm{d}} \mathrm{D}$ & $* 1.75 \pm 0.03^{\mathrm{b}} \mathrm{C}$ & $* 1.47 \pm 0.02^{\mathrm{b}} \mathrm{C}$ & $* 1.07 \pm 0.06^{\mathrm{a}} \mathrm{A}$ & $* 13.30 \pm 0.26^{\mathrm{cd}} \mathrm{D}$ & $* 97.24 \pm 0.20^{\mathrm{c}} \mathrm{D}$ & $* 4.92 \pm 0.06^{\mathrm{c}} \mathrm{C}$ \\
\hline \multirow{6}{*}{$\begin{array}{c}4^{\text {th }} \\
\text { week }\end{array}$} & \multirow{3}{*}{ Ambient } & $1 / 3$ & $* 5.64 \pm 0.15^{\mathrm{a}} \mathrm{B}$ & $* 11.49 \pm 0.38^{b_{B}}$ & $* 1.79 \pm 0.06^{\mathrm{b}} \mathrm{C}$ & $* 0.39 \pm 0.02^{\mathrm{a}} \mathrm{A}$ & $* 1.72 \pm 0.07^{b_{B}}$ & $* 12.19 \pm 0.23^{c} \mathrm{C}$ & $* 84.79 \pm 0.34^{\mathrm{a}} \mathrm{C}$ & $* 4.50 \pm 0.15^{\mathrm{d}} \mathrm{C}$ \\
\hline & & $1 / 4$ & $* 5.49 \pm 0.18^{\mathrm{a}} \mathrm{C}$ & $* 6.41 \pm 0.18^{\mathrm{a}} \mathrm{A}$ & $* 2.13 \pm 0.12^{\mathrm{e}} \mathrm{C}$ & $0.39 \pm 0.01^{\mathrm{a}} \mathrm{A}$ & $* 2.01 \pm 0.04^{\mathrm{c}}{ }_{\mathrm{B}}$ & $* 13.32 \pm 0.24^{\mathrm{d}} \mathrm{D}$ & $* 89.79 \pm 0.20^{\mathrm{b}} \mathrm{D}$ & $* 4.00 \pm 0.05^{\mathrm{a}} \mathrm{A}$ \\
\hline & & $1 / 6$ & $* 5.46 \pm 0.34^{\mathrm{a}}{ }_{\mathrm{B}}$ & $* 16.77 \pm 0.28 \mathrm{~d}_{\mathrm{D}}$ & $* 1.92 \pm 0.04^{\mathrm{d}} \mathrm{C}$ & $* 0.64 \pm 0.04^{\mathrm{b}} \mathrm{A}$ & $* 19.95 \pm 0.61^{\mathrm{e}} \mathrm{B}$ & $* 11.75 \pm 0.13^{\mathrm{c}} \mathrm{C}$ & $* 89.23 \pm 0.33^{\mathrm{b}} \mathrm{C}$ & $* 4.34 \pm 0.22^{\mathrm{c}} \mathrm{A}$ \\
\hline & \multirow{3}{*}{ Refrigerator } & $1 / 3$ & $5.77 \pm 0.12^{\mathrm{a}} \mathrm{D}$ & $* 17.41 \pm 0.25^{\mathrm{e}} \mathrm{D}$ & $1.63 \pm 0.06^{\mathrm{a}} \mathrm{B}$ & $1.57 \pm 0.05^{\mathrm{c}} \mathrm{A}$ & $* 1.08 \pm 0.04^{\mathrm{a}} \mathrm{A}$ & $* 5.72 \pm 0.15^{\mathrm{b}} \mathrm{A}$ & $87.61 \pm 0.36^{b_{B}}$ & $* 4.23 \pm 0.05^{b} \mathrm{C}$ \\
\hline & & $1 / 4$ & $5.61 \pm 0.07^{\mathrm{a}} \mathrm{D}$ & $* 17.60 \pm 0.29^{\mathrm{e}} \mathrm{C}$ & $* 1.81 \pm 0.04^{\mathrm{c}} \mathrm{C}$ & $* 1.81 \pm 0.02^{\mathrm{d}_{\mathrm{B}}}$ & $1.70 \pm 0.08^{\mathrm{b}}{ }_{\mathrm{B}}$ & $* 5.59 \pm 0.10^{\mathrm{b}}{ }_{\mathrm{B}}$ & $* 97.93 \pm 0.06^{\mathrm{d}} \mathrm{C}$ & $* 4.35 \pm 0.04^{\mathrm{c}}{ }_{\mathrm{B}}$ \\
\hline & & $1 / 6$ & $5.62 \pm 0.06^{\mathrm{a}} \mathrm{D}$ & $* 13.84 \pm 0.05^{\mathrm{c}} \mathrm{C}$ & $* 1.88 \pm 0.08^{\mathrm{cd}}{ }_{\mathrm{C}}$ & $0.36 \pm 0.01^{\mathrm{a}} \mathrm{A}$ & $* 2.50 \pm 0.05 \mathrm{~d}_{\mathrm{B}}$ & $* 5.34 \pm 0.05^{\mathrm{a}} \mathrm{C}$ & $* 93.62 \pm 0.18^{\mathrm{c}} \mathrm{C}$ & $* 4.07 \pm 0.05^{\mathrm{a}} \mathrm{B}$ \\
\hline \multirow{6}{*}{$\begin{array}{c}\mathbf{8}^{\text {th }} \\
\text { week }\end{array}$} & \multirow{3}{*}{ Ambient } & $1 / 3$ & $* 4.55 \pm 0.13^{\mathrm{a}} \mathrm{A}$ & $* 14.56 \pm 0.03^{\mathrm{d}} \mathrm{D}$ & $* 0.36 \pm 0.01^{\mathrm{a}} \mathrm{A}$ & $* 0.66 \pm 0.01^{\mathrm{a}} \mathrm{B}$ & $* 2.41 \pm 0.06^{\mathrm{b}} \mathrm{C}$ & $* 3.93 \pm 0.02^{\mathrm{a}} \mathrm{A}$ & $* 39.21 \pm 0.43^{\mathrm{a}} \mathrm{B}$ & $3.60 \pm 0.05^{\mathrm{b}} \mathrm{A}$ \\
\hline & & $1 / 4$ & $* 4.60 \pm 0.02^{\mathrm{a}} \mathrm{A}$ & $* 16.47 \pm 0.19^{\mathrm{e}} \mathrm{D}$ & $* 0.42 \pm 0.01^{\mathrm{b}} \mathrm{A}$ & $* 1.07 \pm 0.06^{\mathrm{d}} \mathrm{C}$ & $* 3.05 \pm 0.08^{\mathrm{e}} \mathrm{C}$ & $* 5.44 \pm 0.05^{\mathrm{c}} \mathrm{A}$ & $* 61.21 \pm 0.07^{\mathrm{d}} \mathrm{B}$ & $* 4.49 \pm 0.10^{\mathrm{e}}{ }_{\mathrm{B}}$ \\
\hline & & $1 / 6$ & $* 4.50 \pm 0.05^{\mathrm{a}} \mathrm{A}$ & $* 14.08 \pm 0.04^{\mathrm{d}} \mathrm{C}$ & $* 0.55 \pm 0.01^{\mathrm{c}} \mathrm{A}$ & $* 0.83 \pm 0.03^{\mathrm{c}} \mathrm{B}$ & $* 24.36 \pm 0.06^{\mathrm{f}} \mathrm{C}$ & $* 4.83 \pm 0.02^{\mathrm{b}} \mathrm{B}$ & $* 50.63 \pm 0.35^{\mathrm{b}}{ }_{\mathrm{B}}$ & $* 4.32 \pm 0.06^{\mathrm{e}} \mathrm{A}$ \\
\hline & \multirow{3}{*}{ Refrigerator } & $1 / 3$ & $* 4.92 \pm 0.03^{\mathrm{c}} \mathrm{B}$ & $* 2.86 \pm 0.03^{\mathrm{b}} \mathrm{B}$ & $* 0.63 \pm 0.01_{\mathrm{A}}^{\mathrm{d}}$ & $* 2.27 \pm 0.01^{\mathrm{e}} \mathrm{B}$ & $1.21 \pm 0.06^{\mathrm{a}} \mathrm{B}$ & $11.52 \pm 0.16^{\mathrm{d}} \mathrm{C}$ & $* 56.55 \pm 0.43^{\mathrm{c}} \mathrm{A}$ & $3.44 \pm 0.02^{\mathrm{a}} \mathrm{A}$ \\
\hline & & $1 / 4$ & $* 4.94 \pm 0.04^{\mathrm{c}}{ }_{\mathrm{B}}$ & $* 4.82 \pm 0.03^{\mathrm{c}} \mathrm{A}$ & $* 0.35 \pm 0.04^{\mathrm{a}} \mathrm{A}$ & $* 0.64 \pm 0.01^{\mathrm{a}} \mathrm{A}$ & $* 2.72 \pm 0.02^{\mathrm{c}} \mathrm{C}$ & $* 4.60 \pm 0.02^{\mathrm{b}} \mathrm{A}$ & $* 63.32 \pm 0.45^{\mathrm{d}} \mathrm{B}$ & $* 4.11 \pm 0.06^{\mathrm{d}} \mathrm{A}$ \\
\hline & & $1 / 6$ & $* 4.79 \pm 0.02^{\mathrm{b}} \mathrm{A}$ & $* 1.24 \pm 0.02^{\mathrm{a}} \mathrm{A}$ & $* 0.39 \pm 0.01^{\mathrm{a}} \mathrm{A}$ & $* 0.75 \pm 0.01^{\mathrm{b}} \mathrm{B}$ & $* 2.98 \pm 0.21^{\mathrm{d}} \mathrm{C}$ & $* 4.75 \pm 0.07^{\mathrm{b}} \mathrm{B}$ & $* 61.73 \pm 0.39^{d_{B}}$ & $* 3.84 \pm 0.05^{\mathrm{c}} \mathrm{A}$ \\
\hline \multirow{6}{*}{$\begin{array}{c}12^{\text {th }} \\
\text { week }\end{array}$} & \multirow{3}{*}{ Ambient } & $1 / 3$ & $4.78 \pm 0.10^{\mathrm{b}} \mathrm{A}$ & $* 7.12 \pm 0.09^{\mathrm{d}} \mathrm{A}$ & $0.56 \pm 0.06^{\mathrm{a}} \mathrm{B}$ & $0.98 \pm 0.01^{\mathrm{a}} \mathrm{C}$ & $3.12 \pm 0.04^{\mathrm{b}} \mathrm{D}$ & $5.46 \pm 0.08^{\mathrm{c}} \mathrm{B}$ & $* 36.50 \pm 0.40^{\mathrm{a}} \mathrm{A}$ & $* 3.90 \pm 0.06^{b}$ \\
\hline & & $1 / 4$ & $* 5.12 \pm 0.06^{\mathrm{d}}{ }_{\mathrm{B}}$ & $* 7.68 \pm 0.10^{\mathrm{e}}{ }_{\mathrm{B}}$ & $* 0.68 \pm 0.08^{\mathrm{b}}{ }_{\mathrm{B}}$ & $* 2.16 \pm 0.06^{\mathrm{b}}{ }_{\mathrm{D}}$ & $* 5.15 \pm 0.08^{\mathrm{d}} \mathrm{D}$ & $* 5.98 \pm 0.05^{\mathrm{d}} \mathrm{B}$ & $* 56.18 \pm 0.24^{\mathrm{e}} \mathrm{A}$ & $* 4.86 \pm 0.04^{\mathrm{e}} \mathrm{C}$ \\
\hline & & $1 / 6$ & $* 5.68 \pm 0.08^{e_{B}}$ & $* 6.08 \pm 0.04^{\mathrm{b}}{ }_{\mathrm{A}}$ & $* 1.65 \pm 0.10^{\mathrm{d}_{\mathrm{B}}}$ & $4.13 \pm 0.03^{\mathrm{d}} \mathrm{D}$ & $* 29.16 \pm 0.16^{\mathrm{e}} \mathrm{D}$ & $* 3.32 \pm 0.06^{\mathrm{a}} \mathrm{A}$ & $* 38.54 \pm 0.15^{\mathrm{b}} \mathrm{A}$ & $* 4.78 \pm 0.04 \mathrm{~d}_{\mathrm{B}}$ \\
\hline & \multirow{3}{*}{ Refrigerator } & $1 / 3$ & $4.45 \pm 0.03^{\mathrm{a}} \mathrm{A}$ & $* 5.86 \pm 0.02^{\mathrm{a}} \mathrm{C}$ & $0.68 \pm 0.02^{\mathrm{b}} \mathrm{A}$ & $* 3.78 \pm 0.04^{\mathrm{c}} \mathrm{C}$ & $1.48 \pm 0.03^{\mathrm{a}} \mathrm{C}$ & $* 10.12 \pm 0.12^{\mathrm{f}} \mathrm{B}$ & $* 58.50 \pm 0.32^{\mathrm{f}} \mathrm{A}$ & $* 3.66 \pm 0.08^{\mathrm{a}} \mathrm{B}$ \\
\hline & & $1 / 4$ & $4.65 \pm 0.10^{\mathrm{b}} \mathrm{A}$ & $* 6.56 \pm 0.08^{c}{ }_{B}$ & $* 0.76 \pm 0.04^{\mathrm{b}}{ }_{\mathrm{B}}$ & $* 5.12 \pm 0.08^{\mathrm{e}} \mathrm{D}$ & $2.95 \pm 0.06^{b}{ }_{D}$ & $* 6.40 \pm 0.08^{\mathrm{e}} \mathrm{C}$ & $* 53.12 \pm 0.12^{\mathrm{d}} \mathrm{A}$ & $* 4.42 \pm 0.06^{c}{ }_{B}$ \\
\hline & & $1 / 6$ & $* 4.98 \pm 0.06^{\mathrm{c}} \mathrm{B}$ & $* 9.19 \pm 0.04^{\mathrm{f}} \mathrm{B}$ & $* 0.88 \pm 0.08^{\mathrm{c}} \mathrm{B}$ & $* 5.88 \pm 0.03^{\mathrm{f}} \mathrm{D}$ & $* 3.78 \pm 0.10^{\mathrm{c}} \mathrm{D}$ & $* 4.15 \pm 0.06^{\mathrm{b}}{ }_{\mathrm{A}}$ & $* 42.48 \pm 0.30^{\mathrm{c}} \mathrm{A}$ & $* 4.96 \pm 0.15^{\mathrm{e}} \mathrm{C}$ \\
\hline
\end{tabular}

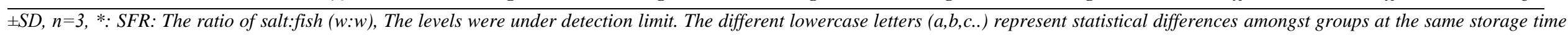

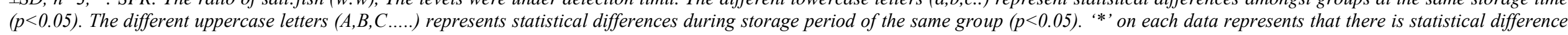
between the data obtained for fresh raw material group relating to the same storage time and the same salt concentration ratio. 
The results of previous studies with commercially processed products showed that high biogenic amine levels can also be obtained with the products containing high salt concentration and kept at cold storage (Köse et al., 2012; Koral et al., 2013). So, the levels of biogenic amine content can also depend on handling and storage of raw materials prior to salting or other processing ways. It was also demonstrated that fresh Atlantic bonito kept at different chilled conditions (Koral and Köse, 2012) had reached to unacceptable histamine values at certain time of storage period. Therefore, handling and storing raw material at suitable time and temperature conditions are important to avoid health risk associated with histamine.

\section{Conclusion}

This study showed that previously frozen raw material had higher salt uptake in comparison with freshly salted Atlantic bonito with the increasing level in parallel to increasing time and salt concentration. Higher WPS\% levels for both raw material groups were found at ambient temperature in comparison to refrigerated conditions.WPS level reached to suggested seafood safety level (20\%) within the same week of salting for all experimental group with the exception of $1 / 6$ group at refrigerated temperature. The $\mathrm{a}_{\mathrm{w}}$ values significantly dropped within the $1^{\text {st }}$ week after salting reaching to seafood safety levels (below 0.83) for all groups at the end of storage. The results showed that although there were significant differences amongst samples treated with different salt ratios and different storage applications, such differences did not affected products' chemical acceptability for salt:fish ratios of $1 / 3$ and $1 / 4$. However, higher the salt used, higher TBA content was observed at both temperatures of both groups. This might have caused due to salt accelerating the lipid oxidation.

Our results demonstrated that dry salting prevents the formation of biogenic amines, particularly histamine in salted Atlantic bonito. In general, lower biogenic amine values were observed with products originated from previously frozen Atlantic bonito compared to freshly processed fish. Histamine values were also found very low and none of the products exceeded the permitted levels.

The results showed that the products with the lowest salt contenthad the lowest sensory acceptance in both raw material groups. Although some significant differences occurred between salt ratios for $1 / 3$ and $1 / 4$ in terms of product quality at both temperatures, such differences did not make a great effect on the sensory quality since each group was within acceptable quality throughout the storage period. Therefore, both salt:fish ratio groups were found suitable for lakerda production from Atlantic bonito. The salt:fish ratio of 1/6 was only found suitable for previously frozen raw materials which were also kept in refrigerated conditions after salting. Therefore, this study demonstrates that using previously frozen raw material may extend the shelf life of dry salted fish products.

Finally, the overall results of this study indicate that dry salting using previously frozen Atlantic bonito have an advantage in relation to both food quality and food safety, particularly if low salt contents intended to be used. Moreover, freezing and frozen storage will help to kill parasites in this type of products contributing to additional benefit in terms of seafood safety.

\section{References}

Amerina, M.A., Pangborn, R.V., Roessler, E.B. (1965). Principles of sensory evaluation of food. New York: Academic Press Inc.ISBN: 9781483225210

AOAC (1985). Official Methods of Analysis. (Official methods 985.14.) Association of Official AnalyticalChemists, Gaithersburg, MD. ISBN: 978-0935584752

Archer, M. (2010). Sensory assessment score sheets for fish and shell fish.Torry\& QIM. Research \& Development Department of Seafish, $58 \mathrm{p}$.

Ateş, C., Deval, M.C., Bök, T. (2008). Age and growth of Atlantic bonito (Sarda sarda Bloch, 1793) in the Sea of Marmara and Black Sea, Turkey. Journal of Applied Ichthyology, 24, 546-550.

Boland, F.E., Paige, D.D. (1971).Collaborative study of a method for the determination of trimethylamine nitrogen in fish, Journal Association of Official Analytical Chemists, 54, 725-727.

Caglak, E., Cakl1, S., K1lınc, B. (2012). Effect of modified atmosphere packaging on quality and shelf life of salted bonito (Sarda sarda). Journal of AquaticFood Product Technology, 21, 206-221.

Eerola, S., Hinkkanen, R., Lindfors, E., Hirvi, T. (1993). Liquid chromatographic determination of biogenic amines in dry sausages. Journal of AOAC International, 76 (3), 575-577. 
Erkan, N., Tosun, Ș.Y., ÜcokAlakavuk, D., Ulusoy, Ş.(2009). Keeping quality of different packaged salted Atlantic bonito 'Lakerda'. Journal of Food Biochemistry, 33, 728-744.

EU Directive (2005a). Commission Regulation (EC) No 2073/2005 of 15 November 2005 on microbiological criteria for foodstuffs. L 338/1 EN Official Journal the European Union.

EU Directive (2005b). Commission Regulation (EC) No 2074/2005 of 5 December 2005 laying down implementing measures for certain products under Regulation (EC) No 853/2004 of the European Parliament. L338/27 EN Official Journal the European Union.

EU Directive (2008). Commission Regulation (EC) No 1022/2008 of 17 October 2008 amending Regulation (EC) No 2074/2005 as regards the total volatile basic nitrogen (TVB-N) limits. L277/18 EN Official Journal the European Union.

FAO-WHO (2013). Joint FAO/WHO Expert Meeting on the Public Health Risks of Histamine and Other Biogenic Amines from Fish and Fishery Products. 23-27 July 2012, Rome, Italy: FAO.

FAO. (2016). Global Capture Fisheries Production Statistics for the year 2012. http://ftp.fao.org/FI/news/GlobalCaptureProductionSt atistics2012.pdf (accessed 01.07.2016).

FDA. 2011. Fish and fishery products hazards and controls guidance. $4^{\text {th }}$ edition.http://www.fda.gov/FoodGuidances (accessed 02.15.2017).

Gonzaga, V.E., Lescano, A.G., Huamàn, A.A., SalmómMulanovich, G. (2009). Histamine levels in fish from markets in Lima, Peru, Journal of Food Protection, 2, 1112-1115.

Goulas, A.E., Kontominos, M.G. (2005). Effect of salting and smoking method on the keeping quality of chub mackerel (Scomber japonicus): biochemical and sensory attributes. Food Chemistry, 93, 511-520.

Hernández-Herrero, M.M., Roig-Sagués, A.X., RodríguezJerez, J.J. \& Mora-Ventura, M.T. (1999). Halotolerant and halophilic histamine-forming bacteria isolated during the ripening of salted anchovies (Engraulis encrasicholus). Journal of Food Protection, 62(5), 509-514.

Huss, H.H. (1988). Fresh fish quality and quality changes. Danish International Development Agency, Rome: FAO.43-45 pp.

Huss, H.H. (1995).Quality and quality changes in fresh fish. Rome, Italy: FAO Fisheries Technical Papers (Book 348). ISBN 92-5-103507-5

Kahraman, E.A., Göktürk, D., Yıldız, T., Uzer, U. (2014). Age, growth, and reproductive biology of Atlantic bonito (Sarda sarda Bloch, 1793) from the Turkish coasts of the Black Sea and the Sea of Marmara.Turkish Journal of Zoology,38, 614-621.

Karaçam, H., Kutlu, S., Köse, S. (2002). Effect of salt concentrations and temperature on the quality and shelflife of brined anchovies. International Journal of Food Science and Technology, 37, 19-28.

Kocatepe, D., Turan, H., Altan, C.O., Göknar, G. (2014). Effect of the Vacuum Packaging on the Shelf Life of Lakerda. International Journal of Food Science Nutrition and Dietetics, 3(9), 157-159.

Koral, S., Köse, S., Tufan, B.(2010).The effect of storage temperature on the chemical and sensorial quality of hot smoked Atlantic bonito (Sarda sarda, Bloch, 1838) packed in aluminium foil. Turkish Journal of Fisheries and Aquatic Sciences, 10, 439-443.

Koral, S., Köse, S. (2012). The effect of filleting and ice application on the quality and safety of Atlantic bonito (Sarda sarda) at refrigerated storage. International Journal of Food Science and Technology, 47, 210-220.

Koral, S., Tufan, B., Scavniçar, A., Koçar, D., Pompe, M., Köse, S. (2013). Investigation of the contents of biogenic amines and some food safety parameters of various commercially salted fish products. Food Control, 32, 597-606.

Köse, S. (2010). Evaluation of seafood safety health hazards for traditional fish products: preventive measures and monitoring issues. Turkish Journal of Fisheries and Aquatic Sciences, 10, 139-160. 
Köse, S., Kaklıkkaya, N., Koral, S., Tufan, B., Buruk, K.C., Aydin, F. (2011). Commercial test kits and the determination of histamine in traditional (ethnic) fish products-evaluation against an EU accepted HPLC method. Food Chemistry, 125, 1490-1497.

Köse, S., Koral, S., Tufan, B., Pompe, M., Scavniçar, A., Koçar, D. (2012). Biogenic amine contents of commercially processed traditional fish products originating from European countries and Turkey. European Food Research and Technology, 235, 669-683.

Lakshmanan, R., Shakila, R.J., Jeyasekaran, G. (2002). Changes in the halophilic amine forming bacterial flora during salt-drying of sardines (Sardinella gibbosa). Food Research International, 35, 541-546.

Lehane, L., Olley, J. (1999).Histamine (Scombroid) Fish Poisoning. A Review in a Risk-Assessment Framework. National Office of Animal and Plant Health Canberra Agricultural, Fisheries and Forestry of Australia, 90 p, LI: 21171252.

Losikoff M. (2008). Clostridium botulinum concerns. In: D.E. Kramer and L. Brown (eds) International smoked seafood conference proceedings (p. 5-7). Alaska, USA: Sea Grant.

Lücke, F., Geidel, W. (1935). Determination of volatile basic nitrogen in fish as a measure of their freshness. Zeitschrift für Lebensmittel Untersuchung und Forschung, 70, 441-458.

Lüleci, E. (1991). Palamut balığının Sarda sarda (Bloch, 1793) lakerdaya işlenmesi ve raf ömrünün belirlenmesi, MSc. Thesis, Fen BilimleriEnstitüsü, İstanbul Üniversitesi.

Minegishi, Y., Tsukamasa, Y., Miake, K., Shimasaki, T., Imai, C., Sugiyama, M.S., Hinano, H. (1995).Water activity and microflora in commercial vacuum-packed smoked salmons. Food Hygiene and Safety Science, 36, 442-446.

Mbarki, R., Sadok, S., Barkallah, I. (2008). Influence of gamma irradiation on microbiological, biochemical, and textural properties of bonito (Sarda sarda) during chilled storage. Food Science and Technology International, 14, 367-373.
Ormanc1, H.B., Colakoglu, F.A. (2017). Changes in biogenic amines levels of lakerda (salted Atlantic bonito) during ripening at different temperatures. Journal of Food Processing and Preservation, 41(1), 1-10.

Rohani, A.C., Arup, M.J. \& Zahrah, T.(2010). Brining parameters for the processing of smoked river carp (Leptobarbus hoevenii). Journal of the Science of Food and Agriculture, 38(1), 51-61.

Schormüller, J. (1969). Handbuch der Lebensmittelchemie (Band III/2). Tierrische Lebensmittel Eier, Fleisch, Fisch, Buttermich, Berlin/Heidelberg: Springer Verlag, Germany.

Smith, G., Hole, M., Hanson, S.W. (1992). Assessment of lipid oxidation in Indonesian salted-dried marine catfish (Arius thalassinus). Journal of the Science of Food and Agriculture, 51, 193-205.

Sokal, R.R., Rohlf, F.J.(1987). Introduction to biostatistics. $2^{\text {nd }}$ edt., New York: W.H. Freeman and Company. ISBN: 978-0486469614

Tarladgis, B.G., Watts, B.M., Dugan, L.R.Jr. (1960). A distillation method for the quantitative determination of malonaldehyde in rancid foods. Journal of AOAC International, 37, 44-48.

Turan, H., Kaya, Y., Erkoyuncu, İ., Sönmez, G. (2006). Chemical and microbiological qualities of dry-salted (Lakerda) bonito (Sarda sarda, Bloch 1793). Journal of Food Quality, 29, 470-478.

TUİK (2016). Turkish Statistical İnstitute, Fishery Statistics Book. Available at: https://biruni.tuik.gov.tr/medas $/$ ?kn=97\&locale $=$ tr $\quad(a c-$ cessed 30.05. 2017).

Zaboukas, N., Miliou, H., Moraitou-Apostolopoulou, M. (2006). Biochemical composition of the Atlantic bonito Sarda sarda from the Aegean Sea (Eastern Mediterranean Sea) in different stages of sexual maturity. Journal of Fish Biology, 69, 347-362. 